\title{
On Beauty and Being an Architect
}

By André Carvalho Assis

A thesis submitted to the Faculty of Graduate and Postdoctoral Affairs in partial fulfillment of the requirements for the degree of:

Master of Architecture

Azrieli School of Architecture and Urbanism

Carleton University

Ottawa, Ontario

(c) 2017

André Carvalho Assis 


\section{Abstract}

The Ontario Association of Architects Code of Ethics states that "members should... strive for design excellence and in so doing, members should thoughtfully consider and respect both the natural and cultural environment of the communities in which they are practicing." But what exactly is design excellence? Does it in any way entail the obligation to make spaces and experiences that are beautiful?

In her book, On Beauty and Being Just, Elaine Scarry argues that beauty presses us toward a greater concern for justice. Based on this work, this thesis explores the significance of beauty and the role that it plays in the experience of the built world. Specifically, the thesis asks, "What guides the hand of the architect when working to reintroduce a lost beauty."

The thesis is tested through a proposal for a site in Ottawa's Lowertown that holds significant historical value, but has suffered from decades of neglect. Only two facades, supported by steel bracing, remain of the original Our Lady's School structure. The proposed design repurposes the existing structure as cooperative housing for senior women. Drawing upon studies documented in Atul Gawande's book, Being Mortal: Medicine and What Matters in the End, the project is designed as a supportive environment for senior women to keep their 
independence and contribute to society by caring for each other under one self-sustaining program. The project concludes with a series of vignettes describing "beautiful moments" that help to refine the definition of beauty and bring attention to the importance of aspiring to beauty in the architectural practice. 


\section{Acknowledgments}

I would like to thank my supervisor, Lucie Fontein, for her guidance, encouragement, and wisdom throughout the development of this thesis.

Most importantly, my deepest gratitude goes to my mother, Raquel, who introduced me to architecture and continues to be my greatest understanding of beauty. 


\section{Table of Contents}

Abstract

Acknowledgments

Table of Contents

Chapter 1: Introduction

1.1 Note to the Reader

1.2 Research Interest

Chapter 2: Beauty and Justice

2.1 On Beauty and Being Just

2.2 Thesis Question

2.3 Mission

Chapter 3: A Lost Beauty

3.1 History of Lowertown West

3.2 History of Proposed Site 
3.3 Current Conditions of Site

3.4 Challenges

\section{Chapter 4: The Need for Independence}

4.1 Being Mortal

4.2 Program Proposal

\section{Chapter 5: Design}

5.1 Form + Space Diagram

5.2 Drawings

5.3 The Beautiful Moment

\section{Chapter 6: Concluding Remarks}

6.1 Response to Thesis Question

\section{List of Illustrations}

Bibliography 


\section{Chapter 1: Introduction}

\subsection{Note to the Reader}

As a student constantly striving to define my role as an architect, it became necessary to direct my thesis project in a direction that would position me best for practice. Throughout my education, I have strategically entered challenging studios, enrolled in demanding courses, and placed myself in front of highly critical professors to become well-disciplined in this field in order to grow in the skill-set and knowledge that an upright architect ought to have. Like every studio project that I have done, I recognize my thesis project as another great opportunity to address real life issues through design while working out of my comfort zone in order to move forward as an architectural designer. As you, the reader, explore my research, concept and design, I hope that you will find this thesis as enjoyable and informative as I have. 


\subsection{Research Interest}

Among the various aspects of architecture that an architect should have a sturdy grasp of, I became most interested in learning about the significance of beauty and architectural ethics. The architect holds a very privileged position-being given the authority to create and construct beautiful spaces for the human body to experience. The constant strive to create beauty is well-embedded in the architect's focus but it seems that many, even after mastering the art, do not understand the significance of beauty and why it is vital for humans to experience it. My goal entering this thesis was to understand if beauty is a mere luxury of life that happens to bring us joy, or if human nourishment is reliant on the exposure to beauty. This would allow me, as a designer, to further understand the importance of my decisions and their impact on humankind. Of course, the obligation to create delightful spaces is not directly stated in the requirements of the architect, so what guides a large sum of the architect's decisions derives from an underlying sense of ethics—designing a space they would find delight in themselves. This idea fascinates me as well and it seems like a topic worth exploring. I became interested in learning about, not what the architect must do, but what he/she ought to do in regard to designing spaces. The significance of beauty and ethics 
seems to be two topics that intertwine, and so, I found it suitable to explore both in one thesis project. 


\section{Chapter 2: Beauty and Justice}

\subsection{On Beauty and Being Just}

Our relationship with beauty has been distrustful. The recognition of its nourishment has

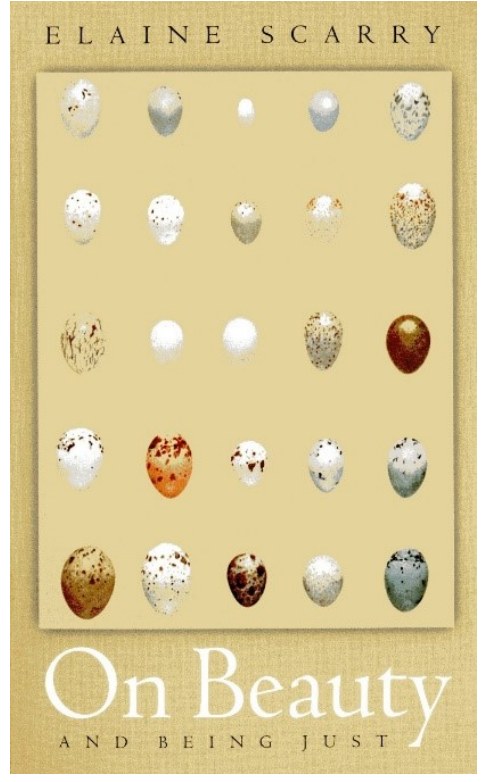

Figure 1 - On Beauty and Being Just been disparaged; its truth—overlooked. What has become of our relationship with beauty?

Our generation appears to be distant from the desires to understand its existence, effects, power, trustworthiness, and security. We are often surrounded by it, yet become too distracted by our daily tasks to consider the present point of our journey in life as an experience worth slowing down for and taking in. Why is it vital to acknowledge beauty as worthy of our admiration and attention? In On Beauty and Being Just, Elaine Scarry answers these questions by linking beauty with morality. She evokes, describes, and manifests the loving attentions that beautiful objects provoke. She argues that this attention leads irresistibly to goodness and truth 1 . Within the realm of morality, beauty is at its centerjustice is made visible. Beauty produces a strong sensation of pleasure encouraging us to gaze at its splendor with an urge to connect it with the rest of the world: "Beauty causes us

\footnotetext{
${ }^{1}$ Nehamas, A. (2000, June 21). Not Rocket Science. Retrieved January 20, 2017, from https://www.Irb.co.uk/v22/n12/alexander-nehamas/not-rocket-science
} 
to gape and suspend all thought ... but simultaneously what is beautiful prompts the mind to move chronologically back into the search for precedents and parallels, to move forward into new acts of creation ... to bring things into relation."2 As we come face-to-face with beauty, Scarry writes, "we undergo a radical decentering."3 Beauty place at the very roots of our sensibility, in our immediate reception of sense impressions and psychological impressions. ${ }^{4}$ Our very own importance becomes diminished: "It is not that we cease to stand at the centre of the world, for we never stood there. It is that we cease to stand even at the centre of our own world. We willingly cede the ground to the thing that stands before us."5 Throughout her book, Scarry brings much clarity to the significance of beauty, how it affects us, and how we ought to treat it. This text has been foundational to the development of this thesis.

Although it has been highly tempting to pinpoint the definition of beauty, it seems it cannot be done, although, there lies plenty of simplicity in what we could understand about it. We often know when we see it, hear it, feel it, or touch it, such as a little boy surprising his mother with a flower that he picked from the garden or watching a leaf on a quiet autumn afternoon

\footnotetext{
2 Scarry, Elaine. On Beauty and Being Just. Princeton, NJ: Princeton University Press, 1999, p. 29

${ }^{3}$ Scarry, Elaine. On Beauty and Being Just. Princeton, NJ: Princeton University Press, 1999, p. 111

${ }^{4}$ Scarry, Elaine. On Beauty and Being Just. Princeton, NJ: Princeton University Press, 1999, p. 111

${ }^{5}$ Scarry, Elaine. On Beauty and Being Just. Princeton, NJ: Princeton University Press, 1999, p. 112
} 
falling ever so gently onto the grass as it peacefully swings, flips, and turns during its slow fall. Times where our minds cease to focus on anything else except the simplicity of the beauty we are joyfully surprised with often pushes us to react to it, protect it, replicate it, reveal it, or draw it. These urges often lead to inspirations and tempts us to interpret what was experienced through art, music, dances, sonnets, poems, philosophic dialogues, theological tracts, as if the joy of beauty overflows and can no longer be contained. Scarry writes about beautiful things having a forward momentum, inciting the desire to bring new things into the world. ${ }^{6}$ It brings us to act selflessly as it would be egotistical if one did not share with the world a glimpse of what was seen or a hint of what was felt. Similar to our infinite ability to express love, there is no capacity limit in our desires for beautiful experiences. We are always willing to experience for a little while longer the beautiful moment we suddenly discovered. As Immanuel Kant mentions in Observations on the Feeling of the Beautiful and Sublime, unlike all other pleasures, the pleasure we take in beauty is inexhaustible. No matter how long beautiful things endure, they cannot out-endure our longing for them. ${ }^{7}$ What should we make of this? If beauty comes to us with no work of

\footnotetext{
${ }^{6}$ Scarry, Elaine. On Beauty and Being Just. Princeton, NJ: Princeton University Press, 1999, p. 46 ${ }^{7}$ Kant, I., \& Goldthwait, J. T. (1981). Observations on the Feeling of the Beautiful and Sublime. Berkeley: University of California Press.
} 
our own, becomes an unquenchable thirst leaving us longing for more, if it places in us the desire to replicate it, are we then left with a duty of our own? It could be that it is not beauty alone that we are attracted to. There seems to be some inner truth embedded in something appealing to our senses. Scarry believes that beauty is allied with truth. By this she does not mean what is beautiful is also true, but there certainly are moments in which "beauty" and "truth" do converge. Artists, poets, and musicians, among all people, should understand the accuracy behind Scarry's statement. When constructing a work of art, writing a sonnet, or composing music, it becomes quite evident when the brush strokes are not expressing the painter's visuals well enough, or when the words are not capturing the poet's message properly, or when there is a missing note in a symphony. In other words, we are capable of acknowledging when we have made an error in beauty, as it sets off a small alarm and warning signs in us. Our desire for beauty, ignites in us, a desire for truth, which we recognize when all objects, musical notes, paint strokes, words, smells, textures, and relationships are working in harmony-firmly placed in their rightful places and behaving in a way that the beholder agrees with.

The role that beauty plays in our lives is worth exploring. If it is correct to say that there lies truth within what we consider beautiful then this matter ought not to be taken lightly. Would 
we be depriving humankind from a life necessity if we attempt to subtract all beauty from their regard? According to Odysseus, "beauty is not life-threatening, but instead it is lifeaffirming, life-giving; and therefore if, through our careless approach, we become cut off from it, we would feel its removal as a retraction of life."8 If this statement is true, we enter this life through a physical birth but it is not until being exposed to the beautiful aspects of this world that our lives becomes affirmed; when we enter into this world a second time. Let us now consider, not only the beholder, but the object beheld. It is safe to say there is a gift that is received by the beholder when given this life-affirming beauty but what is to say about the object beheld? To understand this relationship further, let us consider a very common decision architects make. Often, when designing a house, the architect will place a window above the kitchen sink facing the yard where the garden rests. The kitchen sink is an area in the house we frequently stand by for minutes at a time, and so, placing a window within full view of a garden seems to be a generous decision the architect will make. However, the garden would serve no purpose if it could not be accessed, either visually or physically, so the affirmation of the life of the garden occurs when we perceive, or access, its beauty. Gardens exist for the sake of being beautiful and for the sake of having that beauty looked

\footnotetext{
${ }^{8}$ Scarry, Elaine. On Beauty and Being Just. Princeton, NJ: Princeton University Press, 1999, p. 27
} 
at, walked through, and lingered in. In this respect, the sentient site of gardens is brought into being in order to place their beauty in the field of human regard and the architect, in this scenario, used a window to create such an experience. The moment that we perceive something as beautiful, we recognize we are being given the gift of life through its life affirmation. Now we are beginning to see that the moment of perceiving beauty also confers the object that is being perceived the gift of life. There needs to be this two-part relationship of giving and receiving attention in order for the gift of beauty to be understood. We have a desire, not only to see, but also to be seen by what is beautiful. In On Beauty and Being Just, Scarry writes "Proust watches the glowing red-haired woman serving milk at the train stop and wishes to accompany her in her daily labor in order to keep her in his field of vison; but he has the equally ardent wish to be included in her field of vision, 'to feel that I was known to her, had my place in her thought."'9 How we ought to act when perceiving beauty, or in this case, when we become included in her field of vision, is still uncertain, but we seem to continuously desire our acknowledgement of beauty to be noticed by what is beautiful.

\footnotetext{
${ }^{9}$ Scarry, Elaine. On Beauty and Being Just. Princeton, NJ: Princeton University Press, 1999, p. 76
} 
Make no mistake, when we ponder at what we find attractive we do not wish for ourselves to become beautiful or appealing to what we are perceiving. In this regard, we are beginning to understand how beauty prepares us for justice. Our intentions become an attempt to give beauty the attention we feel it deserves and nothing less. It brings out the best in us as we surrender all that is worrisome to become caught up in the simplicity of the moment. Let us give some consideration to the way we behave. On one hand, we do not wish to interrupt or destroy beauty through carelessness or how we treat it, but on the other hand beauty seems to place in us an urge to protect it, or act on its behalf, in a way that appears to be tied up with the perception of its lifelikeness. ${ }^{10}$ It is as if beauty speaks to us, asking us to act on its behalf but we are uncertain as to how to appropriately execute these desires to respond to this call. By being given these unexpected unselfish desires of protecting, revealing, and interpreting what we find beautiful, it seems we have opened our eyes to something new. These beautiful moments appear to have been placed in this world to serve as small wakeup calls to our perception, triggering an alertness back to a simple state-of-mind. ${ }^{11}$ There is

\footnotetext{
${ }^{10}$ Scarry, Elaine. On Beauty and Being Just. Princeton, NJ: Princeton University Press, 1999, p. 80

${ }^{11}$ Scarry, Elaine. On Beauty and Being Just. Princeton, NJ: Princeton University Press, 1999, p. 81
} 
something the world is attempting to say or remind us of through its splendor-through these small glimpses of something great, much greater than we could ever know.

How do we begin to treat this privileged position we've been placed in? Does beauty itself demand anything from us? Scarry believes there is a role beauty asks us to play when she writes, "permitted to inhabit neither the realm of the ideal nor the realm of the real, to be neither aspiration nor companion, beauty comes to us like a fugitive bird unable to fly, unable to land."12 Beauty has not fully arrived, we have not seen it land as it has no resting place yet. Our mission may just be to offer beauty our hand in assistance, in guidance, helping it reach its destination, placing it firmly in human regard, allowing its magnificence, protection, tranquility, and lifelikeness to dwell in us. We are relying on a modern notion of distribution of what is beautiful to take place. As architects, we are beginning to understand the significance of our positions and our decisions_-being given the opportunity to give beauty a landing place through the art and science of building.

\footnotetext{
${ }^{12}$ Scarry, Elaine. On Beauty and Being Just. Princeton, NJ: Princeton University Press, 1999, p. 86
} 


\subsection{Thesis Question}

To become disciplined in architectural ethics, it is necessary to readjust the motive behind the decision-making process. If understanding the role of beauty is to be pursued through the guidance of Elaine Scarry's On Beauty and Being Just, one approach for this thesis is to consider a situation where beautiful moments have been lost, are struggling to be revealed, and are in need of assistance. The design challenge selected for study is the site of the former Our Lady Girls School in Lowertown, Ottawa. This is a site that is struggling to find a purpose and failing to contribute to the current demands of society. The site has a rich history but lacks the beauty that it once had. Specifically, the question being asked is in this thesis is:

What guides the hand of the architect when working to reintroduce a lost beauty? 


\subsection{Mission}

Since Vitruvius laid out the foundation of architectural principals for future generations to build on, we have been given a vast number of theories advancing principles for creating beauty in architecture. The evolution of these theories is on-going. This thesis does not aim to analyze, criticize, or compare the principles of creating beauty put forward over the centuries, as such a task would exceed the time frame given for this study. Instead, this thesis focuses specifically on applying Elaine Scarry's interpretation of beauty onto a design project. By doing so, I hope to demonstrate that beauty, truth, justice, and morality are all intertwined, as Scarry argues convincingly in her book, On Beauty and Being Just. To test her theory, the mission is to engage a program that speaks to integrity, preserve and enrich a lost beauty, and provide a catalyst for community development and exchange. 


\section{Chapter 3: A Lost Beauty}

\subsection{History of Lowertown West}

The Lowertown West Heritage Conservation District includes multiple blocks of residential and institutional development within Ottawa's central core. The district is immediately north of the Byward Market, south of the Ottawa River and east of the Rideau Canal. Lowertown West contains the oldest area of residential settlement in the City of Ottawa, with development starting in $1827 . .^{13}$ The dwellings in Lowertown West demonstrate a wide range of architectural types. The richness of the heritage character of Lowertown West is strongly related to the variety of these buildings, their various materials, scale and form, and the

Figure 2 - Lowertown West Aerial view layering of additions and alterations that have occurred over time. Lowertown West is recognized under Part V of the Ontario Heritage Act by the City of Ottawa in 1994 (By-law 192-94).

\footnotetext{
13 Lowertown West Heritage Conservation District. (2011, September 28). Retrieved October 17 2016, from http://www.historicplaces.ca/en/rep-reg/place-lieu.aspx?id=8446.
} 


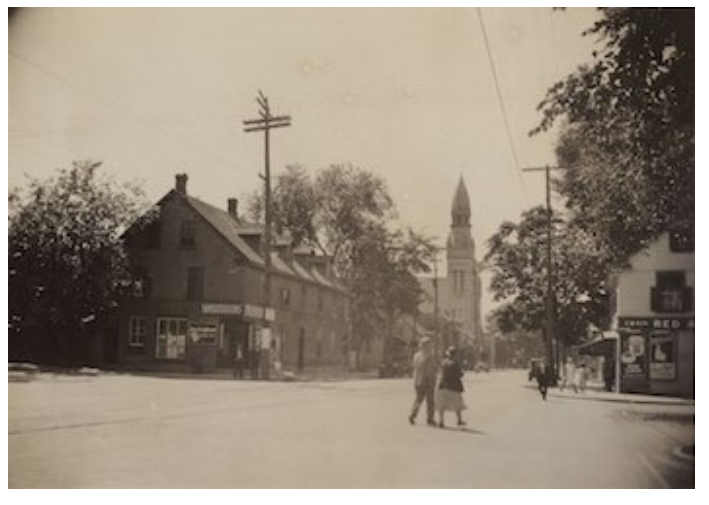

Figure 3 - St. Patrick Street, 1968
After the Vesting Act in 1843, land was finally granted with deeds of ownership, and institutions gained a greater prominence in Lowertown, most notably the Roman Catholic Church. Lowertown experienced another period of population growth starting in the 1870s, despite a crushing depression that greatly affected its working-class inhabitants. During this period, Sussex drive was built up and the Catholic institutions expanded. From about 1890 to the mid-1970s growth occurred in other areas of the city at the expense of Lowertown and much historic fabric of Lowertown east of King Edward and north of Boteler was demolished during urban renewal. ${ }^{14}$

The heritage value of Lowertown West is also derived from its associations with the histories of the working-class Irish and French settlers of Ottawa. Most inhabitants of Lowertown were traveling laborers, working on the canal in the earliest years, or connected with the squared timber trade. The physical record of that social history, represented by both the institutions and the residential buildings, is a major cultural resource for the City of Ottawa. The early population of Lowertown was more than half Irish Catholic, with the remainder being French

${ }^{14}$ Stewart, J. J. (2015, November 25). A Cultural Heritage Impact Statement: 287, 281-283 Cumberland Street \& 207 - 20 Murray Street Ottawa, Ontario [PDF]. Ottawa: Commonwealth Resource Management, p. 17 
Canadian. ${ }^{15}$ However, toward the end of the 19th century, the French presence in Lowertown grew as the Irish Catholics moved to other parts of the city. While overall ethnic and religious profiles remained fairly stable in Ottawa, occupational profiles shifted strongly as the Civil Service tripled its employees between 1900 and 1910 and Lowertown quickly evolved from a laborer's neighborhood to one which served government employees. ${ }^{16}$ In Lowertown West, we find a history and culture that is rich and highly valuable to the City of Ottawa as it is evidence of an important aspect of the origins of the city.

\footnotetext{
15 Lowertown West Heritage Conservation District. (2011, September 28). Retrieved October 17 2016, from http://www.historicplaces.ca/en/rep-reg/place-lieu.aspx?id=8446.

${ }^{16}$ Lowertown West Heritage Conservation District. (2011, September 28). Retrieved October 17,

2016, from http://www.historicplaces.ca/en/rep-reg/place-lieu.aspx?id=8446
} 


\subsection{History of the Proposed Site}

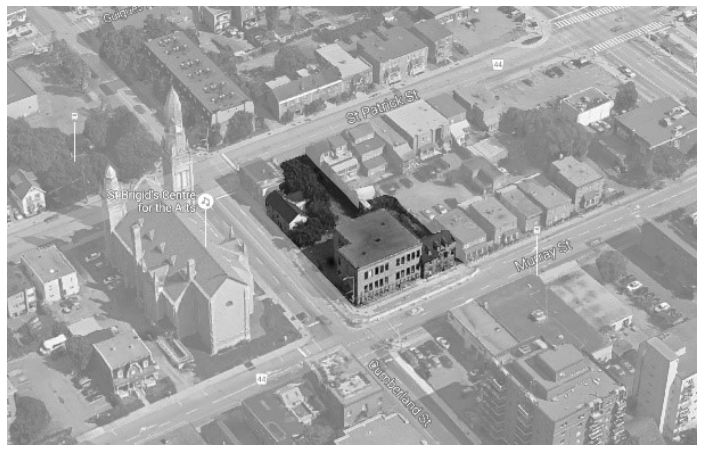

Figure 4-287 Cumberland Street

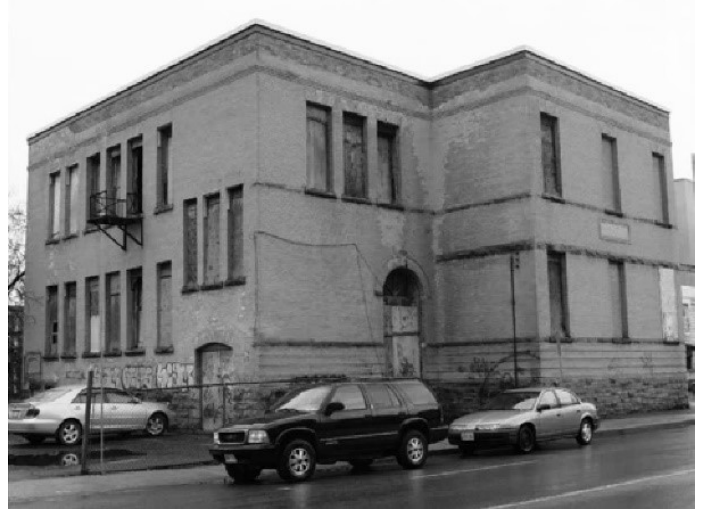

Figure 5 - Our Lady School, 2005
Located at the intersection of Murray Street and Cumberland Street in the Byward Market, the site was originally part of the Ordnance Lands or the Dalhousie Purchase. ${ }^{17}$ By 1843 , the area had been subdivided into residential lots and the first building within the block bound by Murray, Cumberland, St. Patrick and King Edward had been constructed. By 1878, the block was developed with single and side-by-side residential buildings, and the first school (Notre Dame School) had been constructed within the lot as well as on two other corners of the Murray Cumberland intersection. By 1901, St. Brigid's Church had been constructed on St. Patrick Street as well as the existing brick clad residence at the corner of St. Patrick Street and Cumberland Street. The two schools at the intersection of Murray Street and Cumberland Street, including St. Brigid's School on the site of St. Brigid's Church, had been relocated or torn down. In 1904, the original school on the site was demolished, and the Our Lady's School building was constructed. Little changed between 1904 and 1912 within the

17 Stewart, J. J. (2015, November 25). A Cultural Heritage Impact Statement: 287, 281-283 Cumberland Street \& 207 - 20 Murray Street Ottawa, Ontario [PDF]. Ottawa: Commonwealth Resource Management, p. 13 


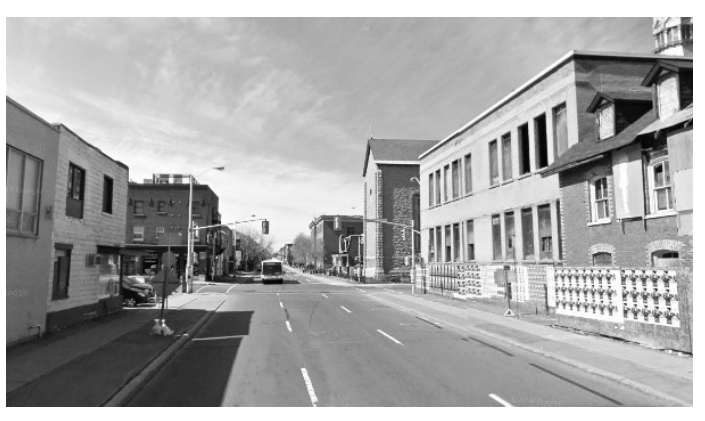

Figure 6 - Murray / Cumberland Intersection block. The area was primarily a residential enclave which by 1912 was beginning to see some commercial development to the south along Cumberland Street. ${ }^{18}$

The intersection of Murray Street and Cumberland Street serves as an important gateway to the district and establishes the heritage character of the area surrounding the site. The significance of the Our Lady's School building, whose facades currently still stand on the site, is derived in part from its history (association with persons) and architecture (integrity), which received the highest scores possible in the evaluation. The evaluation identified the building as a Category 2 heritage resource, which is described as a building of high heritage significance. ${ }^{19}$

18 Stewart, J. J. (2015, November 25). A Cultural Heritage Impact Statement: 287, 281-283 Cumberland Street \& 207 - 20 Murray Street Ottawa, Ontario [PDF]. Ottawa: Commonwealth Resource Management, p. 14 - 16

${ }^{19}$ Stewart, J. J. (2015, November 25). A Cultural Heritage Impact Statement: 287, 281-283 Cumberland Street \& 207 - 20 Murray Street Ottawa, Ontario [PDF]. Ottawa: Commonwealth Resource Management, p. 8 


\subsection{Current Conditions of Site}

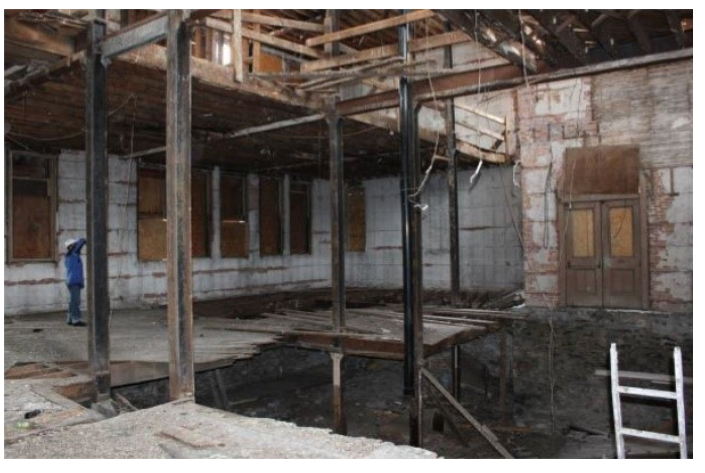

Figure 7 - Our Lady School Interior, 2013

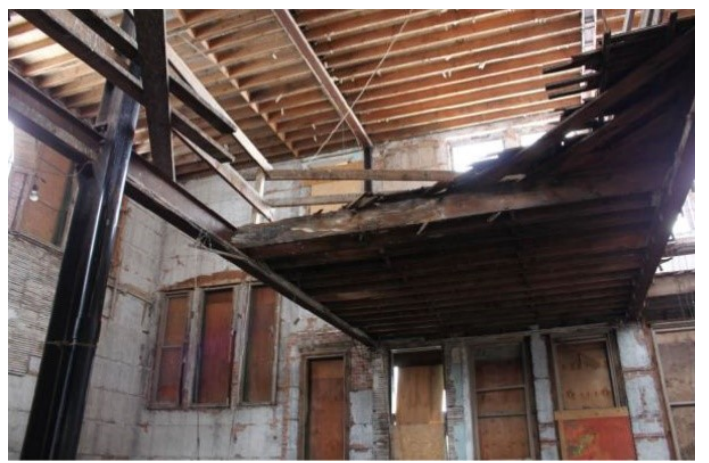

Figure 8 - Our Lady School Interior, 2013
Built in 1904, records show that the Roman Catholic religious institution of Our Lady's School at 287 Cumberland Street relocated in the 1950 s and has not been in use since then. ${ }^{20}$ It was a two-storey, steel frame brick structure, with a high basement. After years of deteriorating, in the winter of 2013 , the old Our Lady's School building was deemed to be in an unsafe condition, and on February 4, 2014 the City issued orders instructing the owners to secure the building and to erect a protective hoarding around it and its neighbor, 207-209 Murray Street, to ensure public safety. Engineers described the condition of the building in its entirety as "not salvageable." 21 Given that the building is recognized as a heritage

\footnotetext{
20 Moser, J. L. (2015, December 10). Application to demolish 281-283 Cumberland Street and Application for new construction at 281-283 Cumberland, 297 Cumberland Street and 207-209 Murray Street, properties located in the Lowertown West Heritage Conservation District (Rep. No. ACS2015-PAI-PGM-0182). Retrieved September 27, 2016, from City of Ottawa Department of Planning and Infrastructure website:

http://app05.ottawa.ca/sirepub/cache/2/0ei04iu4bnnpaqjxex3yeogh/3257250317201704424881 7.PDF, p. 3

${ }^{21}$ Moser, J. L. (2015, December 10). Application to demolish 281-283 Cumberland Street and Application for new construction at 281-283 Cumberland, 297 Cumberland Street and 207-209 Murray Street, properties located in the Lowertown West Heritage Conservation District (Rep. No. ACS2015-PAI-PGM-0182). Retrieved September 27, 2016, from City of Ottawa Department of Planning and Infrastructure website:

http://app05.ottawa.ca/sirepub/cache/2/0ei04iu4bnnpaqjxex3yeogh/3257250317201704424881 7.PDF, p. 4
} 


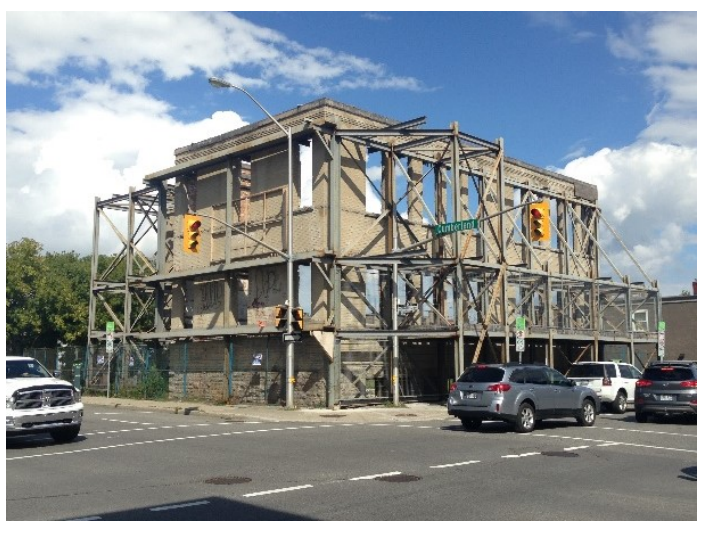

Figure 9 - Our Lady School Exterior, 2017

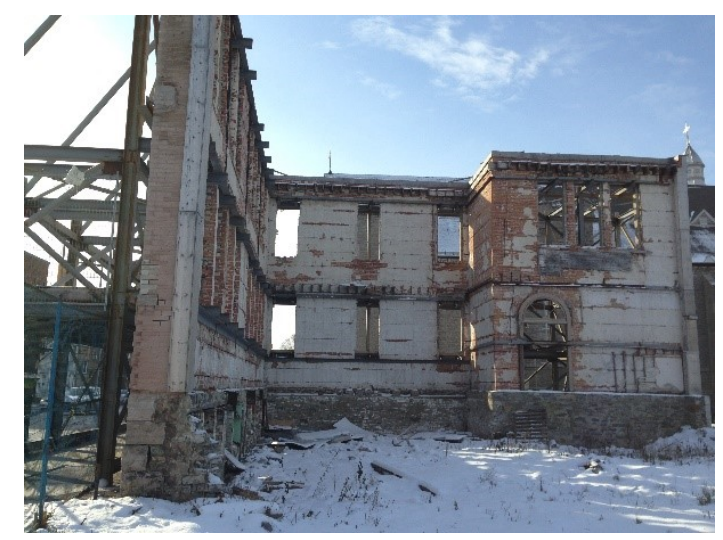

Figure 10 - Our Lady School Interior, 2017 building, complete demolition was an undesirable option. As an alternative, it was decided to retain the south and west walls of the structure, and stabilize them through the erection of steel beams and braces until they could be incorporated into a new development. The rest of the structure was demolished.

Essentially, the site is in ruins after years of neglect and decay, however, the building still appears quite dominant in stature. It currently consists of ten small window openings at the basement level, thirteen large window openings on the first floor, sixteen large window openings on the second floor and the original main entrance on the west wall with a large semi-circle arched header. It has been the recipient of some graffiti over the years but a majority of that has been washed away. The façade consists of a light beige colored brick that still appears quite strong and healthy with bands of gray stone running across the window-sills and lintels. At the basement level, a stone pattern breaks the brick dominated façade standing at a meter in height and complements the brick. Inside, almost half of the original drywall has come off revealing the aged red bricks. The sixteen window openings on the second floor have slightly arched brick lintels. In some areas, the rust of the supporting steel frame has stained the brick and drywall. A steel I-beam enters through each of the first-floor window openings and is joined by another L-shaped beam running 


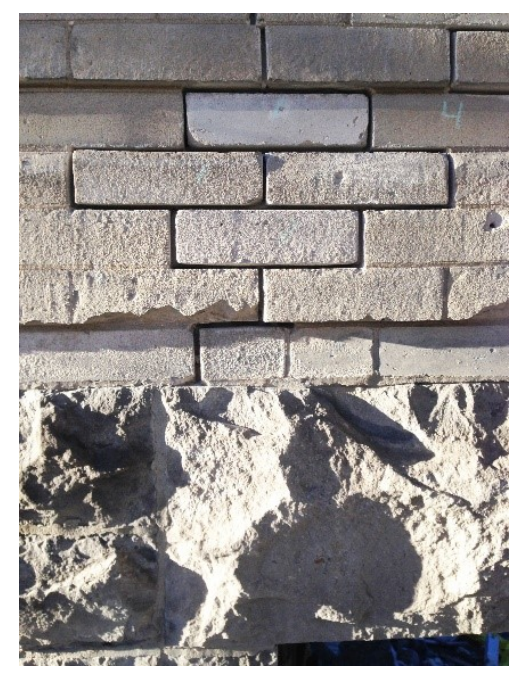

Figure 11 - Our Lady School - Material

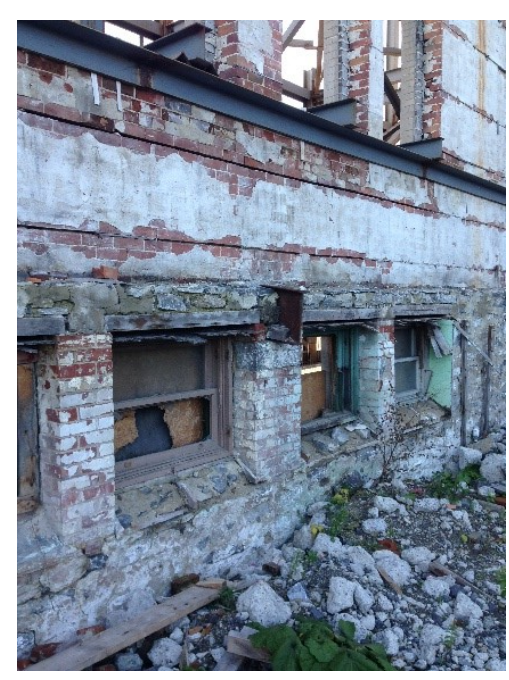

Figure 12 - Our Lady School - Material horizontally against the inner walls at the window sill level. On the second floor the same can be said with the exception that the I-beams and L-shaped beams are at the lintel level rather than the sill. Only a few of the original wooden window frames remain but only at the basement level and above the main entrance opening. It is quite difficult to find two bricks or two stones that are identical. Each appears to have developed its own character overtime which is expressed in the way it is held in place by the mortar, by the stains left by the peeled drywall, and by the occasional chip. The color variation of the brick ranges from a dark red to a light orange while the stones range widely in scale and form. Overall the existing structure expresses the characteristics of a fighter who indeed has aged but has a presence and stature whose beauty has drastically changed. 


\subsection{Challenges}

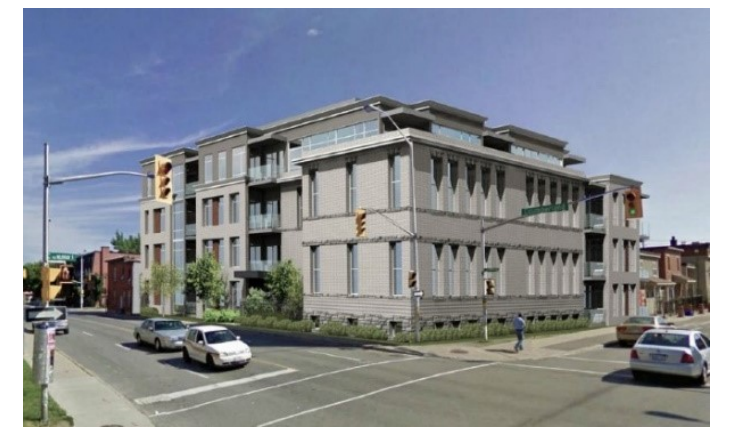

Figure 13 - Our Lady School - Development Proposal

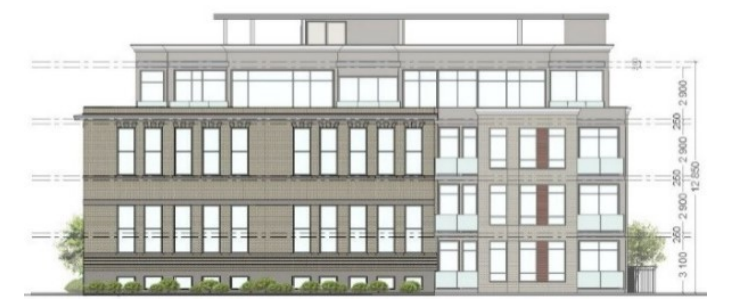

Figure 14 - Our Lady School - Development Proposal
On November of 2015 a proposal to build a four-storey residential building attached to the Our Lady's School walls was made. The proposal overpowered the structure in scale, did not respect the heritage walls through set-backs, and did not conform to the architectural language of the adjacent heritage buildings on the block. Liz Bernstein, President of the Lowertown Community Association, replied to the proposal stating, "As currently proposed, the new construction at this site does not harmonize with the existing heritage building on Cumberland, the retained walls of Our Lady's or these adjacent buildings. It is out of context in terms of scale, design, materials and detailing. It should be stepped down and stepped back to provide a transition from the retained walls of Our Lady's School and the adjacent properties."22 The development company made the mistake of treating the facades, along with the rest of the site, as if it had no value or historical significance. Although the site is

\footnotetext{
22 Bernstein, L. (2015, December 15). Re: Demolition of 281-283 Cumberland, 287 Cumberland site development, using the retained walls of the former school on this site. Infill at vacant property 207-209 Murray (Rep. No. 36575403182017050433950). Retrieved September 23, 2016, from Lowertown Basseville Community Association website: http://app05.ottawa.ca/sirepub_fr/cache/2/c0zf3hddltw4t11oopejsios/365754031820170504339 50.PDF, p. 4
} 


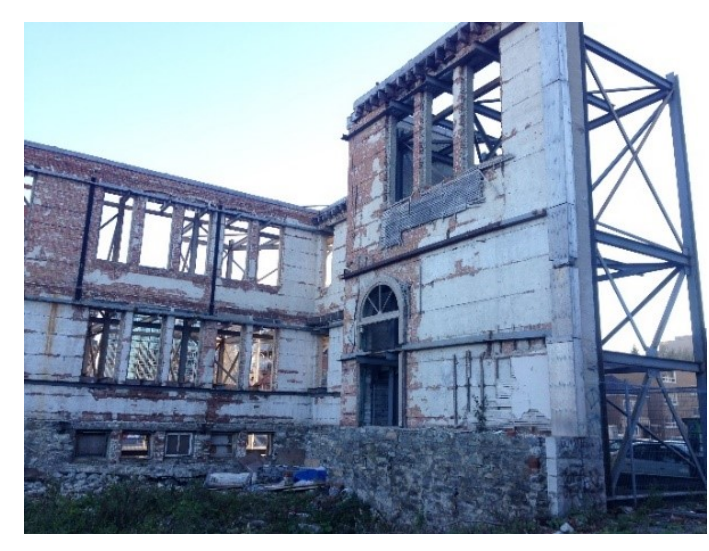

Figure 15 - Our Lady School Interior, 2017

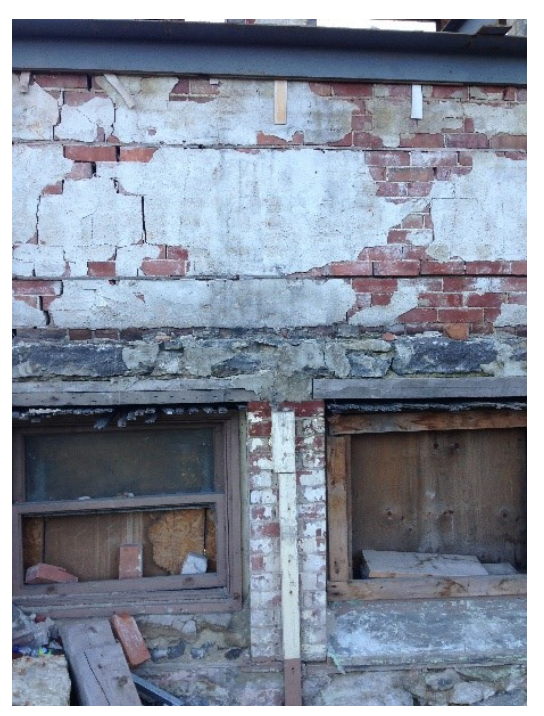

Figure 16 - Our Lady School Interior Detail, 2017 deteriorating, its essence is rich and requires a special level of design delicacy. Clearly, ethical guidance is needed to appropriately design on a site with such history and worth.

The Our Lady School building, serving as a girl's Catholic school, was part of a story much greater than its own. The school helped young girls grow spiritually and morally, however, the teachings of religious institutions can never be confined to the individual or a building. The intention for those growing in faith is to allow the teachings to spread and be shared with their neighbors. Programmatically, I believe this is a vital role that ought to be played in any proposal on this site-a use that is more giving than it is taking, and should be part of a mission that reaches out to those in need of some form of growth. Given that the Lowertown West neighborhood has a rich Catholic history, the site served a purpose that the community approved of and was delighted in. This is another key factor that the previous development proposal in 2015 lacked but needs to be taken into consideration if architectural ethics are involved. The new proposal should bring a form of community engagement and contribute to the neighborhood's current needs if it is to be more considerate than self-serving.

In historical conservation projects, one objective is generally to retain the essence of the old structure. The physical status of the 287 Cumberland Street makes this mission quite 
impossible given that a majority of the original structure is no longer present. There remains only a small portion of what once existed so the existing walls need to be treated with caution and delicacy. To treat the walls as normal facades in any proposal does not do justice to the historical significance of these few remains. It cannot simply be a façade that receives a 'face-lift'. The challenge is discovering a relationship between a new building proposal and the historically rich, but damaged, structure that does not remove any of its value but helps to reveal it even more. As the walls age and their character begins to change, they reveal to us something new and quite special. As the wooden frames fall off, the dry wall peels away, and the structure become more vulnerable, we begin to see a new beauty that is revealing itself. We are now exposed to the aged and hard-working brick still fighting to be purposeful. That being said, this new beauty is in need of assistance to fully reveal itself, which becomes a highly significant challenge for any architect. 


\section{Chapter 4: The Need for Independence}

\subsection{Being Mortal}

\#1 NEW YORK TIMES BESTSELLER

Atul Gawande

\section{Being Mortal}

Medicine and What Matters in the End

Figure 17 - Being Mortal: Medicine and What Happens in the End
Being Mortal: Medicine and What Matters in the End by Dr. Atul Gawande accurately reveals the current issues we face regarding the quality of life for seniors and how we ought to move forward with them. Gawande is an American surgeon and public health researcher who shares many stories about his experience working with elderly patients.

In his book, Gawande begins by expressing how over time, scientific advances have turned aging into a medical experience that requires medical professionals to assist. This has led to the development of senior nursing and retirement homes that focus on keeping seniors physically safe and as healthy as possible, but, this is often at the expense of their emotional well-being. "More than half of the very old now live without a spouse and are having fewer children than ever before, yet we give virtually no thought to how we will live out our later years alone."23

\footnotetext{
${ }^{23}$ Gawande, Atul, author. (2014). Being Mortal: Medicine and What Matters in the End. New York: Metropolitan Books, Henry Holt and Company, p. 36
} 
It is not death that the very old fear. It is what happens short of death-losing their hearing, their memory, their best friends, their way of life. Old age continues to be a series of losses. Gawande describes a couple married nearly 70 years, Bella and Felix. Bella was not doing well as her sight became extremely poor, struggled with hearing, and had a hard time remembering things. The two really struggled, however, having each other was all they wanted. "Felix found great purpose in caring for her, and she, likewise, found great meaning in being there for him. The physical presence gave them comfort...those moments, Felix said, remained the most cherished."24 As things got worse, Felix had no choice but to put Bella in a nursing home. Felix was saddened to see that his beloved was being treated as a patient as nurses and doctors paid little attention to the small things that made Bella comfortable. Felix knew the way she preferred eating, how she liked her pillow placed and the way she preferred putting on her dress. All the small details of comfort that is only found in a real home were absent. This was not a home for living but an institution for treatment.

Gawande shares a similar story about Alice who unwillingly ended up in a retirement home. Out of respect, Alice's daughter attempted to recreate Alice's original home, from the way

${ }^{24}$ Gawande, Atul, author. (2014). Being Mortal: Medicine and What Matters in the End. New York: Metropolitan Books, Henry Holt and Company, p. 56 
she organized her kitchen to the way she set up her bathroom sink. Unfortunately, she still was not at all happy there. Gawande writes, "By removing independence, one is more likely to fall into depression" 25 which is exactly what occurred in Alice's situation. Regardless of her conditions, she hated being taken care of by nurses-all she wanted was to live on her own and keep her independence. She describes that what she missed the most were friendships, privacy, and purpose in her days. ${ }^{26}$ Gawande states, "Once you lose your physical independence, a life of worth and freedom is simply not possible." 27

Another elderly woman by the name of Jessie described to her daughter her ideal living situation as an elderly woman. Her daughter later writes:

"She wanted a small place with a little kitchen and a bathroom. It would have her favorite things in it, including her cat, her unfinished projects, her Vicks VapoRub, a coffeepot, and cigarettes. There would be people to help her with the things she couldn't do without help. In the imaginary place, she

\footnotetext{
${ }^{25}$ Gawande, Atul, author. (2014). Being Mortal: Medicine and What Matters in the End. New York: Metropolitan Books, Henry Holt and Company, p. 61

${ }^{26}$ Gawande, Atul, author. (2014). Being Mortal: Medicine and What Matters in the End. New York: Metropolitan Books, Henry Holt and Company, p. 75

${ }^{27}$ Gawande, Atul, author. (2014). Being Mortal: Medicine and What Matters in the End. New York: Metropolitan Books, Henry Holt and Company, p. 75
} 
would be able to lock her door, control her heat, and have her own furniture.

No one would make her get up, turn off her favorite soaps, or ruin her clothes. Nor could anyone throw out her "collection" of back issues and magazines and Goodwill treasures because they were a safety hazard. She could have privacy whenever she wanted, and no one could make her get dressed, take her medicine, or go to activities she did not like. She would be Jessie again, a person living in an apartment instead of a patient in a bed." 28

We understand here that the demands of the elderly don't appear to be much-they're quite simple really. It's as if we just haven't been listening. Our worries in offering the elderly complete independence is that no one will be there if there is a fall or an emergency. The solution is not to segregate and supervise this population but just to make sure that there are caring people around who will notice if someone needs help.

${ }^{28}$ Gawande, Atul, author. (2014). Being Mortal: Medicine and What Matters in the End. New York: Metropolitan Books, Henry Holt and Company, p. 88 
Finally, Gawande describes how simple it is to give the elderly a purpose in life. A study conducted at a nursing home in New Berlin, New York describes the outcome when a nursing home adopted two dogs, four cats, and one hundred birds. Each senior was given one caged bird to keep in his or her room and was asked to take care of the bird. In addition, a large number of plants were introduced into the building, which also required attention and care. To their surprise, seniors began volunteering to walk the dogs even though the nursing staff was responsible for doing that. After a two-year study between this nursing home and one which did not introduce plants and animals to the seniors, it was discovered that the total drug cost to sustain the New Berlin home fell 38 percent and deaths fell 15 percent. ${ }^{29}$

${ }^{29}$ Gawande, Atul, author. (2014). Being Mortal: Medicine and What Matters in the End. New York: Metropolitan Books, Henry Holt and Company, p. 123 


\subsection{Program Proposal}

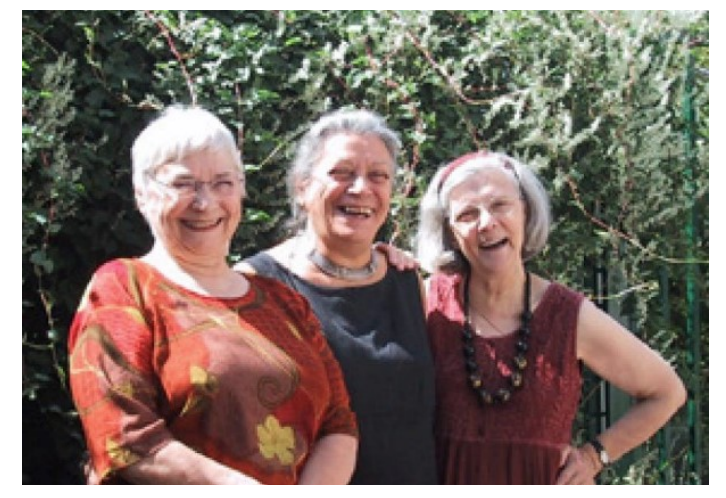

Figure 18 - Babayagas' House Founders
In response to the assertions outlined in Gawande's book, this thesis proposes a cooperative housing project for senior women. The program is inspired by the Babayagas' House, a movement started in Paris in 2012 as a feminist alternative to the retirement home. The inaugural project that opened in 2013 consisted of a 5-storey building in the heart of Montreuil with 25 self-contained apartments and community and outreach programs on the ground floor. Since then, two other houses have opened in other regions of France. Residents are selected partly in relation to what they can contribute to the community as well as the extent to which they share the Babayaga philosophy. These housing projects tackle many of the current issues seniors face today in North America including neglect, lack of purpose, boredom, loneliness, and lack of independence.

The program for the Lowertown site borrows from the Babayaga philosophy and proposes a self-managed social housing project devised and run by a community of dynamic female 
senior citizens who want to keep their independence, but live communally. ${ }^{30}$ This thesis targets women for a number of reasons based on Canadian statistics ${ }^{31}$ :

1. Out of the 4.8 million people 65 years and over, $56 \%$ were women

2. Women have a longer life expectancy than men

3. After a divorce, women are less likely to remarry

4. The percentage of women aged 65 and over in low income remains two times higher than men.

There appears to be greater struggles for the senior woman as they are living longer, have a lower income, and are in much higher risk a being alone at an old age.

${ }^{30}$ Hird, A. (2013, March 05). The Babayagas' House, a Feminist Alternative to Old People's Homes, Opens in Paris. Retrieved January 10, 2017, from http://en.rfi.fr/france/20130305-babayagashouse

${ }^{31}$ Milan, A., \& Vézina, M. (2010). Women in Canada, 2010: a gender-based statistical

report (503rd ed., Vol. 89, X) (Canada, Government of Canada, Statistics Canada). Ottawa, ON: Statistics Canada. Retrieved October 10, 2016, from http://www.statcan.gc.ca/pub/89-503-

x/2010001/article/11441-eng.htm\#a21 


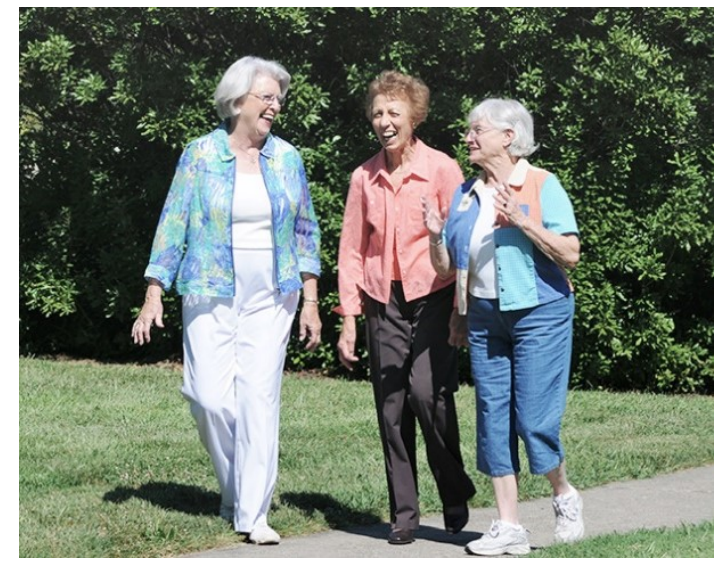

Figure 19 - Senior Women Together
Twenty women will occupy small independent apartment units and will have both the privilege of being cared for by their house-mates and the responsibility to look after them as well. They will have the option of cooking for themselves in their own apartments or sharing meals that they would cook in a larger communal kitchen. Maintenance of a kitchen garden and ornamental garden would also be the responsibility of the participants.

The project also proposes a series of spaces within the design that is dedicated to community workshops. This would allow the women to recycle the knowledge, wisdom, and skills acquired throughout their lives by teaching each other and younger generations in the neighborhood. In this way, the project would have a positive impact on the community as it once did when the site served as a Girl's Catholic School.

The first floor of the design consists of the shared spaces that will create key moments of interaction between the women including a dining room, living room and kitchen adjacent to two gardens. The opposite end of the building houses spaces that require a bit more quiet including a library, offices, and the community workshop flexible space. Workshops are not limited to just one room as, depending on the lesson, could be in the kitchen or garden as well. The upper floors are more private with living units adjacent to communal laundry rooms 
and a fitness center which may also be a workshop. Each of the twenty living units have a bedroom, living space, bathroom, kitchenette, balcony, and storage closet, all of which are wheelchair accessible. 


\section{Chapter 5: Design}

5.1 Form + Space Diagram

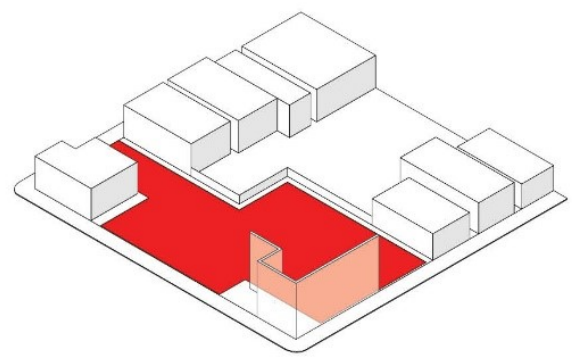

1. Site $-16,000$ sq. ft.

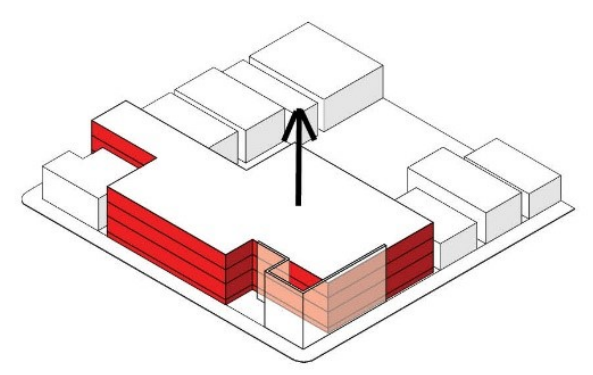

2. Three floors + basement

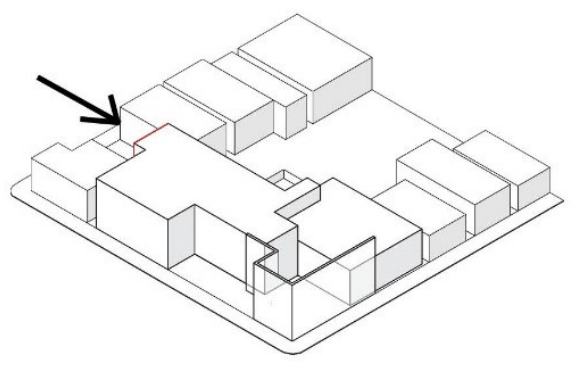

5. Setback for corner building

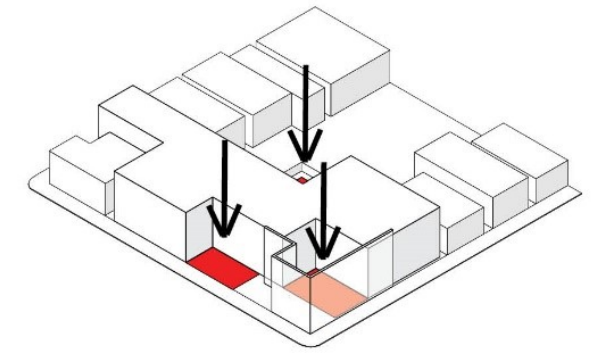

3. Gardens

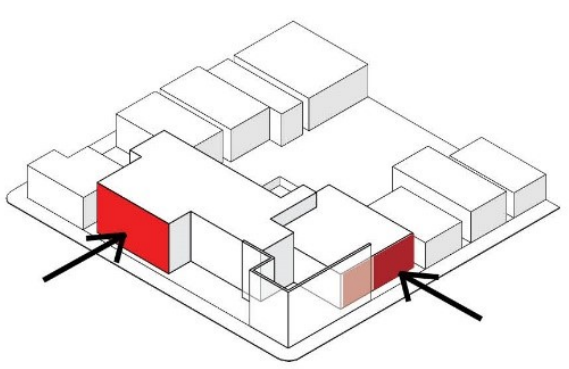

6. Setbacks for existing facade

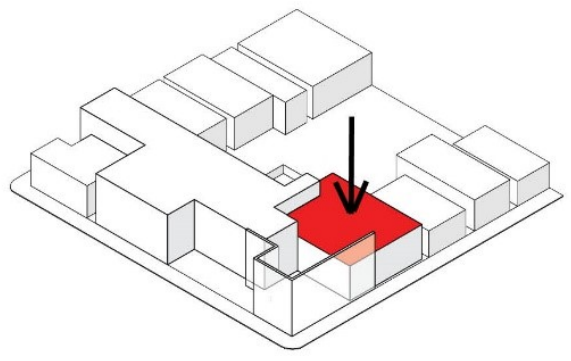

4. Street scale

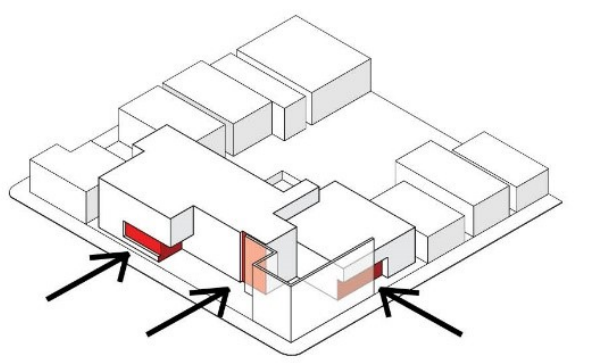

7. Setbacks for pathways + large windows 


\subsection{Drawings}

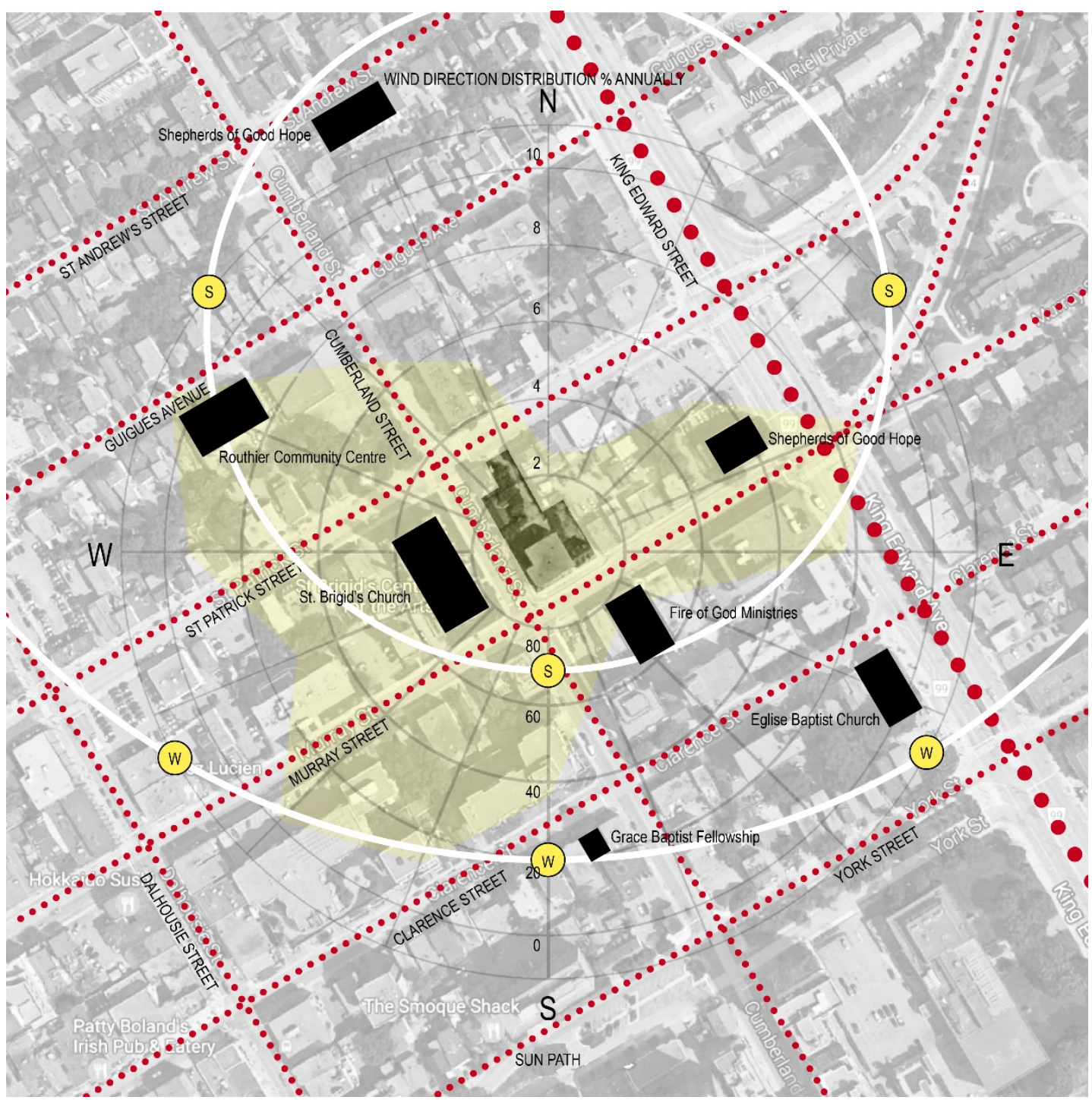

Figure 21 - Site Analysis 


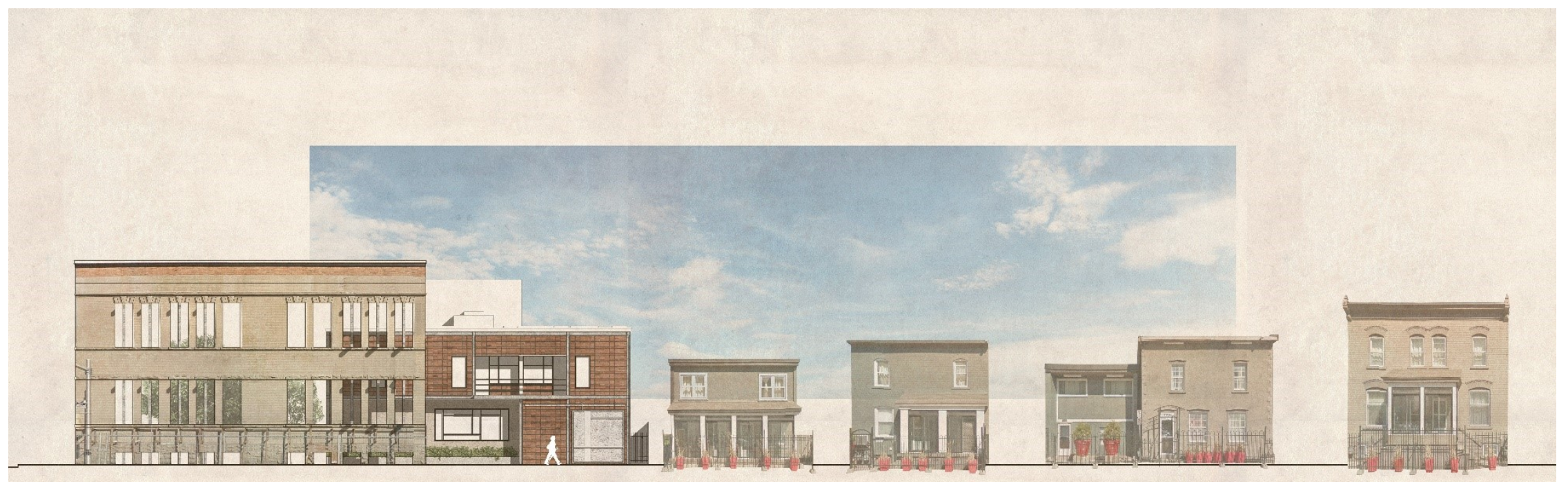

Figure 22 - South Elevation

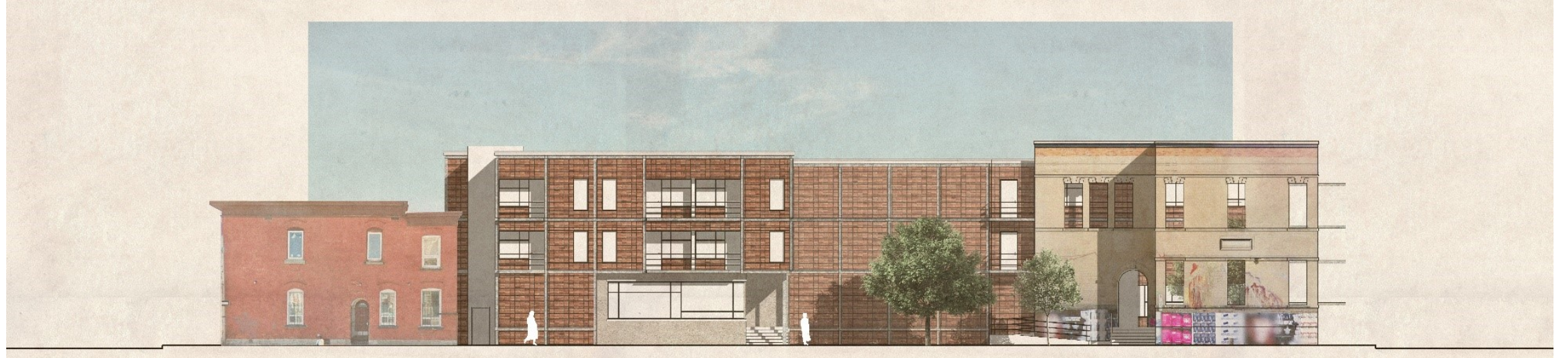

Figure 23 - West Elevation 


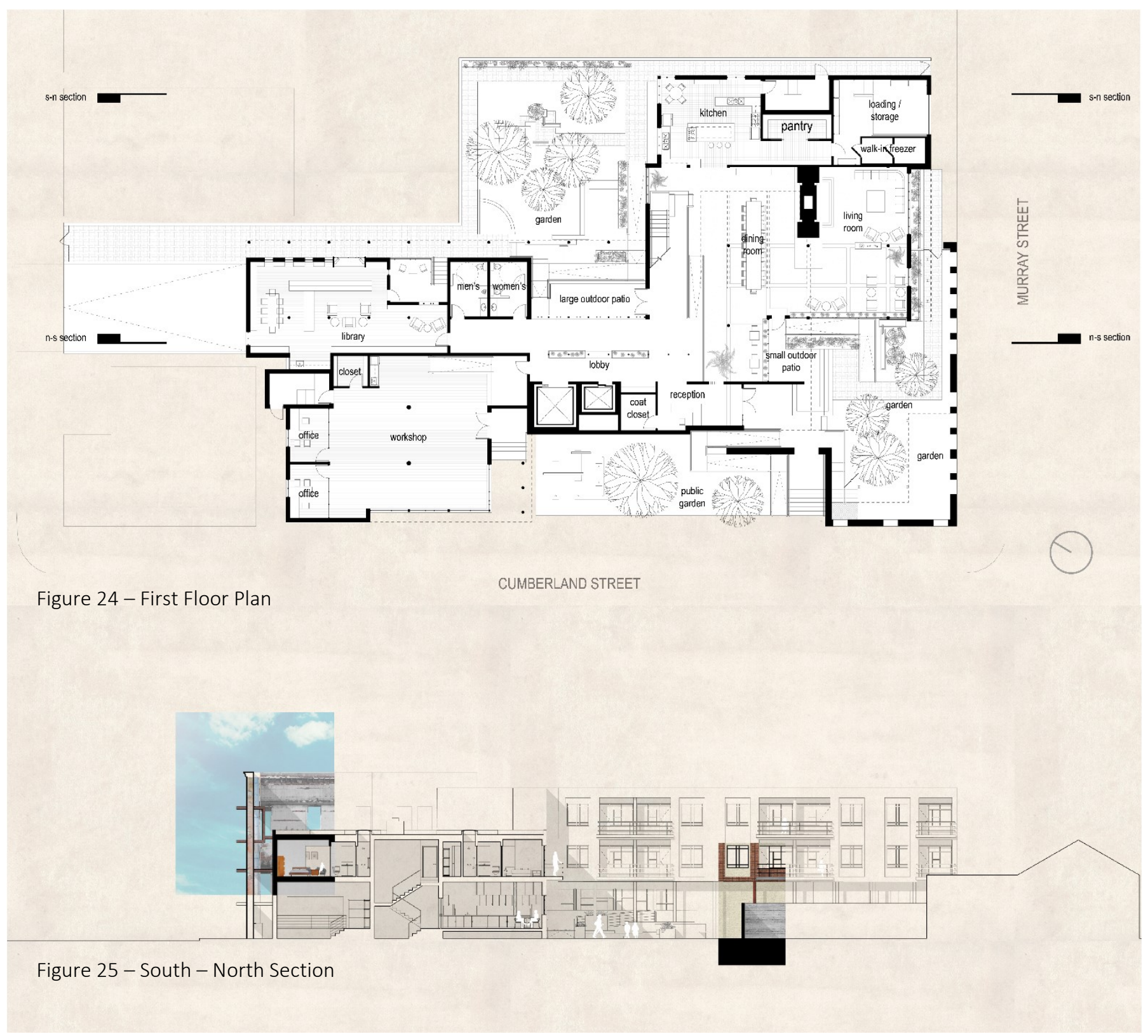




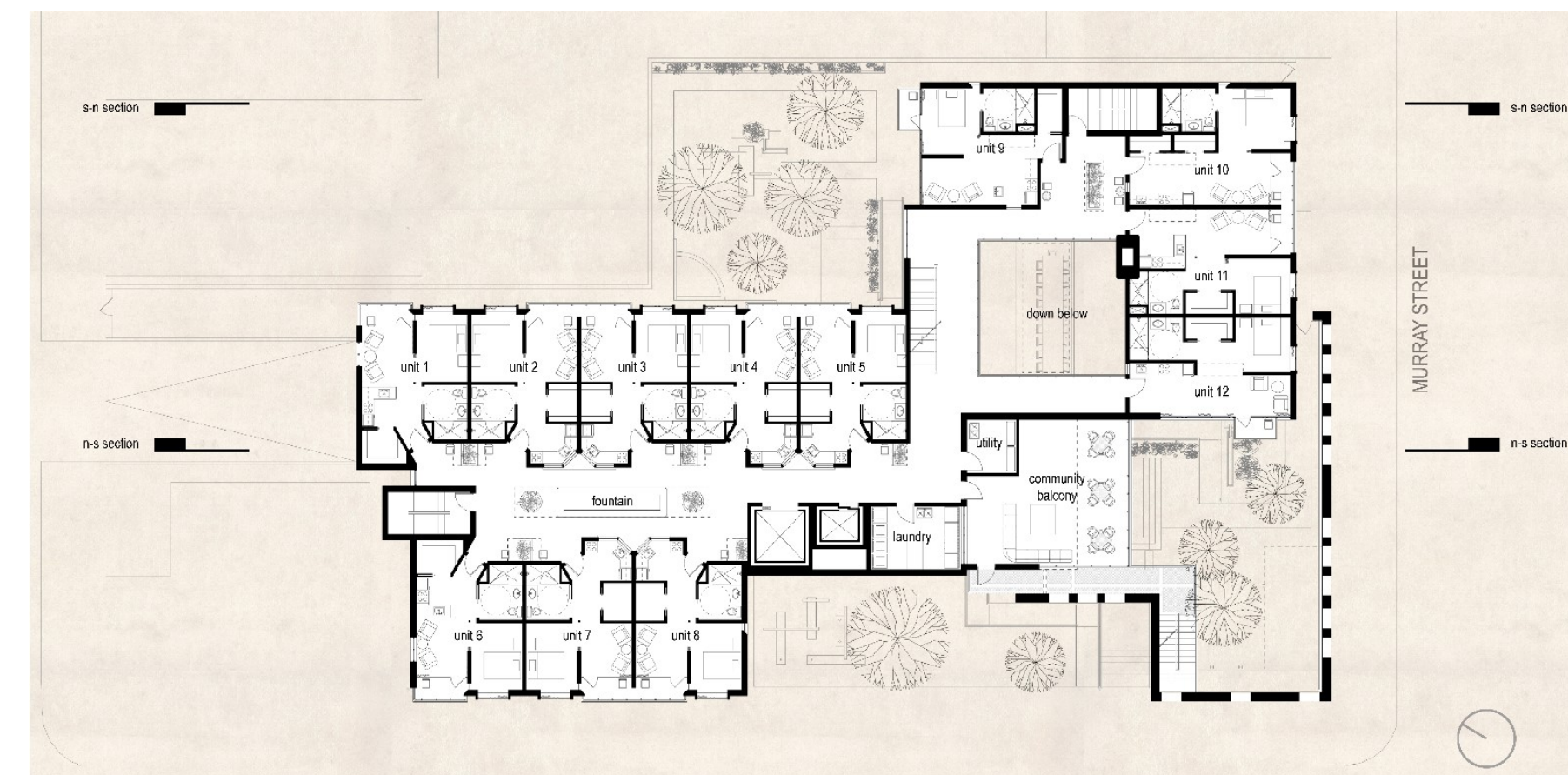

Figure 26 - Second Floor Plan

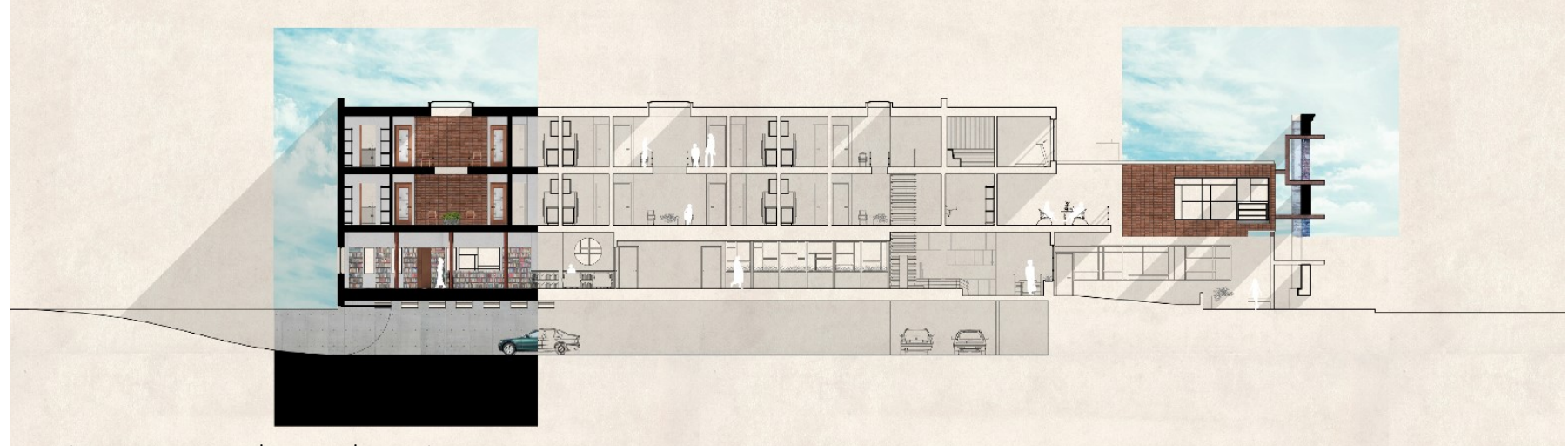

Figure 27 - North - South Section 


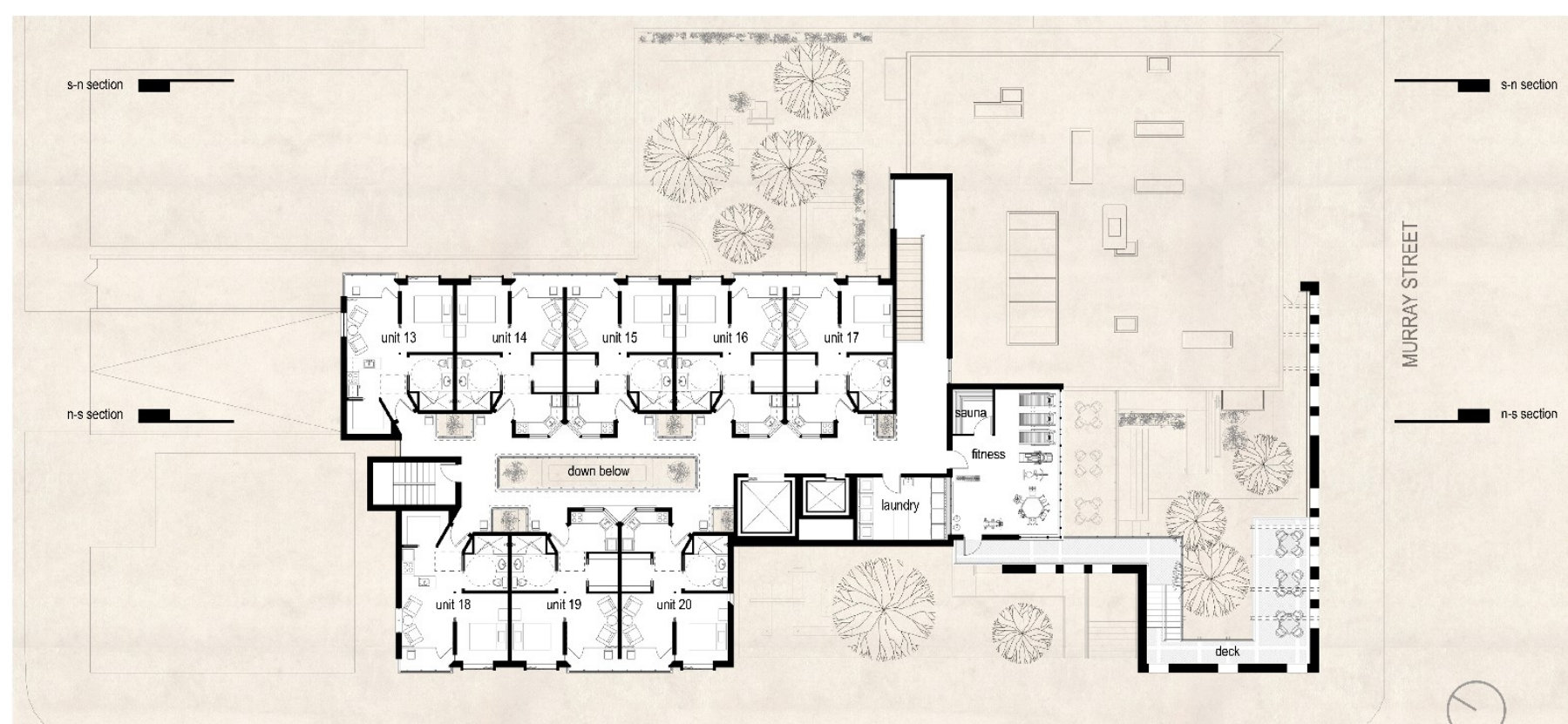

Figure 28 - Third Floor Plan

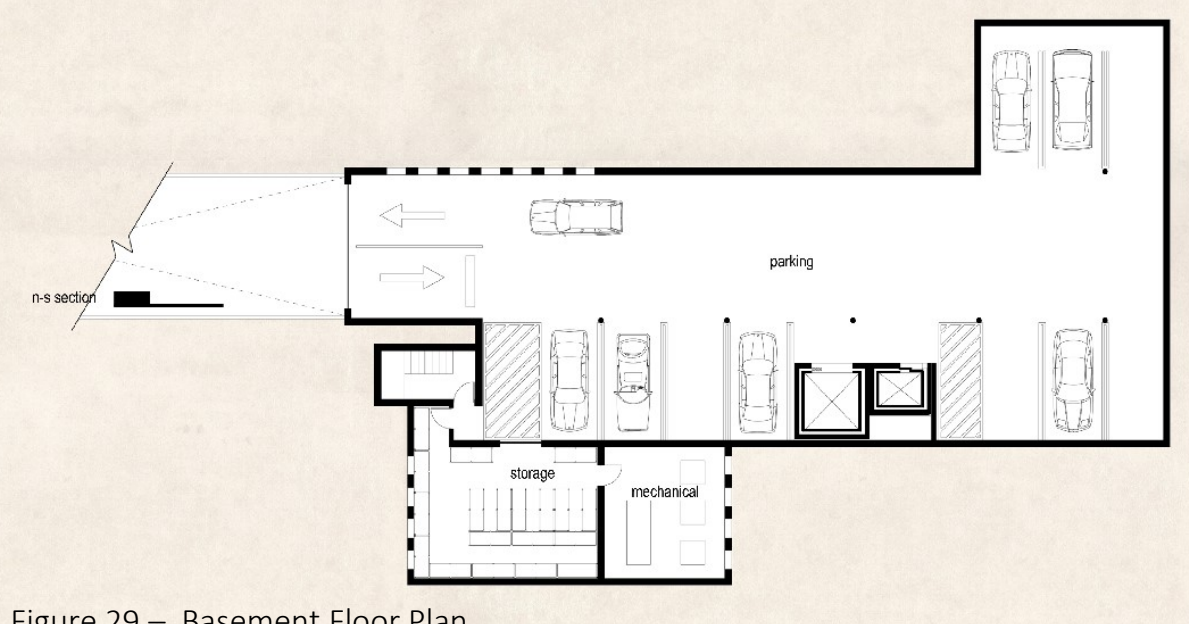

Figure 29 - Basement Floor Plan 


\subsection{The Beautiful Moment}

It is vital for architects to define what beauty is to them, as a means to guide their decisions in creating spaces for the human experience. Decisions require an aim, an objective, and, given the privilege architects have to create and distribute beauty, they ought to understand what beauty is to them first. Criticism, an architect will always receive, but what is beautiful to someone cannot be taken from them. There are key moments in the design of a building which bring the occupant to a peaceful state of mind-moments where beauty nearly forces us to escape from all thought and allows what is being beheld to occupy our full attention. As Elaine Scarry mentions, when perceiving beauty, we remove ourselves from the center and place beauty in its place. In these moments, we are encouraged to slow down in the course of reaching a destination. When transitioning from one space to another, we stop perhaps and ponder at the cloudy sky visible through a well-placed window, enjoy the pleasant breeze coming in through the open double-doors, or become moved by the unique shadow patterns drawn on the wall as the sunlight filters through the suspended staircase. These become gracious moments where we are surprised with a gift, a calming and simple moment that brings ease to the mind and delight to the experience of transitioning through spaces. 


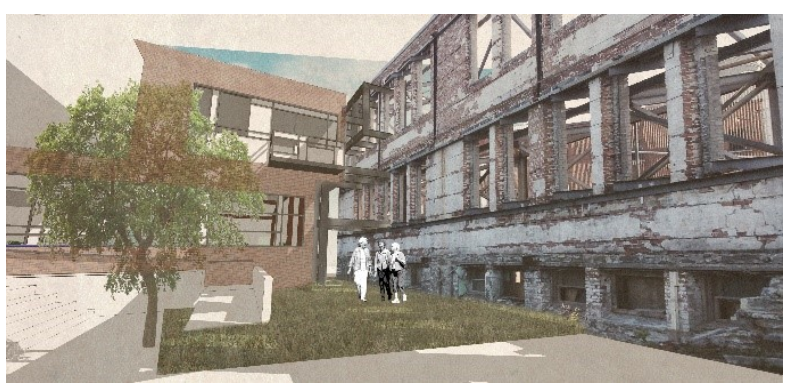

Figure 30 - Garden
When we consider how we move throughout a space, it becomes much more delightful to walk towards what invites us rather than being forced, guided or pushed to a destination due to restrictions. Let us consider the way we circulate through an outdoor community park. Part of the tranquility we experience in the great outdoors is caused by the opportunity to move freely. Nothing fully restricts us from wandering through the woods or over the rocky area on the other side of the lake. We simply let the desires of our senses direct us, pulling us to what is most delightful, making our journey pleasurable, and occasionally adventurous. The architect ought to have a similar intention when creating a circulation that is desirable. An opening serving as the entrance to a new space should be unique, appealing, inviting, and should create curiosity. There ought to be dozens of ways to walk through and experience a garden. It should create the desire and opportunity to linger in its beauty freely. The freedom of our own will is a vital necessity of life and we make decisions because of that freedom. To emphasize that freedom, and encourage it, the design of a 'do as you will' space seems to reconnect us with human nature.

In a corridor, the eye should not only be restricted to the destination but should be offered windows to see the garden, material detail that asks to be more than glanced at, the possibility to walk over the sunlight cast on the ground. As well, it should create opportunities 
for social interactions. The goal is to create experiences that are inviting. It is the journey of the transition that should encourage the circulation without directly dictating it. The beautiful moment in moving through a space is becoming forgetful about the destination upon reaching it, as the journey itself graciously acquired all of one's attention.

In relation to this notion of freedom we are speaking of, let us now consider a line the architect should not cross. Every person has a different definition of what comfort means to them in regards to how they live at home. Person 'A' may prefer to keep their bed near the window in order to see the stars before going to sleep and waking up when the sunlight kisses their face in the morning. Person ' $B$ ' may prefer to have a desk to work on adjacent to the window as the visual access to the outdoors subconsciously inspires them to work better. Person ' $A$ ' may find that a living room is the ideal place to display paintings, photographs and plants while person "B' may find that the simplicity of minimalism is ideal as the living room is a great place to read and be at peace, and so, should be free from distractions. A beautiful space is not restrictive as to how it could be personalized through furniture, plants, paintings, etc. No two people see comfort the same way. The beauty of a space should be amplified through the character it is given by the person filling it. Architecture is not complete until the human body occupies it-allowing its beauty to be 


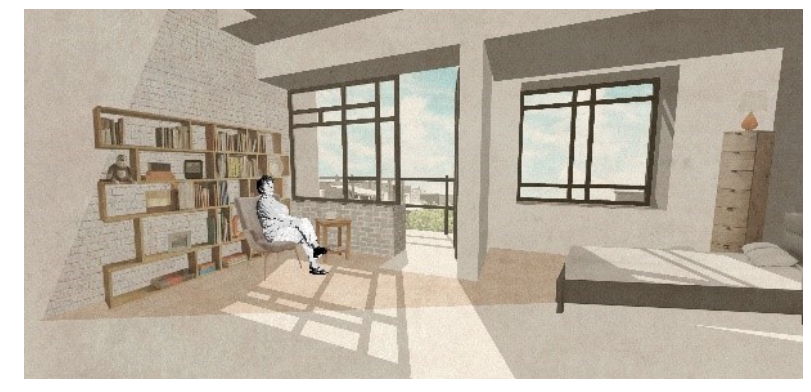

Figure 31 - Bedroom perceived and spaces to take the shape of human personalization. A room that could only function properly if the bed, couch, or table were placed in a particular way gives little to no possibility for people to comfortably express themselves freely-depriving them of their own independence.

A good building will not only be used to fulfill its main function but will invite the mind and encourage the eye to explore its elements. Architecture, combining the art and science of building, should, like a work of art, bring one to a state of questioning. "I wonder why the architect decided to join those two surfaces in that way?" "This window seems isolated from the others, yet, seems highly significant." We are capable of quickly recognizing if a detail in a building is beautiful before we understand its significance as the heart feels the joy of beauty before the mind understands why that is so. That state of seeking understanding is a sign that the architect has created a question, a beautiful question, which the occupant finds seeking an answer to worthwhile. This questioning should not be mistaken for confusion, as it should bring pleasure in seeking its understanding rather than discomfort. Here, the architect has created more than just a beautiful moment, or a beautiful question, he/she has created a miniature escape from time. In the moment we come face-to-face with something beautiful, we lose focus from just about everything else-as nothing is more 
satisfying than cherishing that very moment. Beauty will interfere in our destination in the most pleasant way.

When considering what our eyes find appealing, it is generally not perfection that will attract us the most, but the result of something that has been hand-crafted, expressing the hours of labor that was put into its creation. Beauty is being able to learn about an architect, artist, music composer, author, fashion designer, or a chef through the self-expression that becomes embedded in their creations. Any human creation will teach us something about the one who created it. There is a gift we receive when knowing that someone personally crafted a work of art to be intentionally placed in our field of vision. This is one of the ways beauty leads us to justice. When we perceive something as beautiful, we learn to cherish it. Since it has brought us joy, our instinct becomes to place it in its rightful place in our protection. When an architect gives his work the level of attention where he or she is working to discover a firm placement for all aspects of a building, and it is apparent that no brick was laid carelessly, we become more prone to perceive that building as beautiful. One of the lessons learned from Elaine Scarry's On Beauty and Being Just is that our understanding of what beauty is derives from our understanding of where beauty is lacking. In other words, when there is an error in beauty there is a small white flag that goes up in our minds as if it 
were asking for our assistance in correcting it. In relation to that, as beings able to create beautiful things, we understand when we have done something correctly. In architecture, when a window is carefully placed in its rightful place, allowing us to get a wonderful glimpse of the tree outside while walking through the dining room or when the main staircase allows for us to gracefully enter the living room, that is when we can agree that the window and the staircase have been firmly placed in the correct place. The way two surfaces are joined together also needs to be done carefully, as it will become obvious when it is done poorly. An example we could consider is the way two people hold hands. Person 'A' reaches out their hand and opens it symbolizing an invitation to join with person 'B'. When the offer is accepted, person 'B' reaches out and comes in physical contact with person ' $A$ ' but the union is only complete once both persons decide to interlock through the wrapping of their fingers around the other person's hand. This union is voluntarily, never forced, and it becomes understood that it is done appropriately since, similarly to two hands coming together, the joining should feel as if they always belonged in union as both hands express that they are physically fit for one another. When two surfaces come together, their joining should also feel like they are doing so willingly rather than forcefully. This may be done through a physical interlocking or even a gentle touching of one another. Regardless, it should be 
complementary and work to reveal the other's significance. The way two surfaces come together should not be complicated to discover since it involves listening to how the surfaces are asking to be joined. It should also be stated that not all materials and surfaces are fit to be joined in union. The architect must act as a composer-placing the right musical notes where they are asking to be placed and then simply putting their request into motion.

One of the greatest beauties know to architecture is when the sun hits a surface. Louis Kahn once said that "architecture appears for the first time when the sunlight hits a wall. The sunlight did not know what it was before it hit a wall."32 Although the decision to include windows in buildings are partly due to our desire to look at the beautiful outdoors, they respond also to our need for sunlight to enter the interior. Kahn is right. Is there a single surface in a building that would not benefit from having the warm sunlight touching it? In doing so, we are confirming our need for the sunlight to reveal beauty in what we build. Architecture becomes life-affirming which leads to one of the purposes of the sun being fulfilled-by bringing visibility to what was not yet fully seen. It is when the sun is low in the sky, such as early in the morning or late in the afternoon, that it seems to beautify a space

32 Von Meiss, Pierre. (1992). Elements of Architecture: From Form to Place. London: E \& FN Spon., p. 121 
most. With its low angles, creating long shadows and streams of light, we begin to see all aspects of a room being revealed in a new and pleasing way. A great architect will have a sturdy understanding of how to capture and emphasize these moments to the advantage of the building. It may be more desirable for the early sunlight to enter a bedroom and kitchen and the later sun to enter the living room, main hallway, and foyer. One of the most delightful moments in a building could be walking down a long hallway through the orange light streams of a late afternoon sun coming in through a set of carefully placed windows.

Another thing to consider are the shadows that are cast from the sunlight. These may be

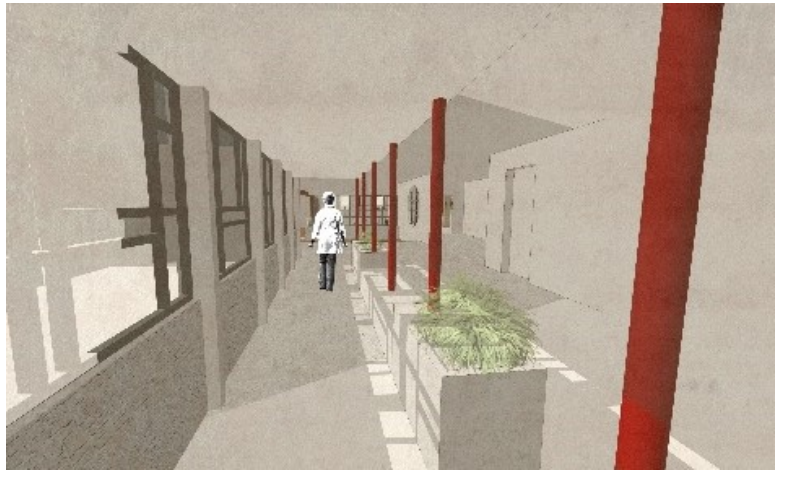

Figure 32 - Transition Space just as relevant and important as the light itself. They each play a role in revealing one another. Dark spaces help to better reveal bright spaces the same way that a bright space helps to better reveal the dark. In that regard, the way light enters a space may be considered delightful, not just for the light that enters, but because of the beautiful shadow that are cast on a surface because of it. For this reason, windows should consist frames whose shadow language would be appealing when filtered onto a surface. Consider the moment one sits under a small tree in September around two o'clock in the afternoon. The sunlight hits the tree but only a small amount of light filters through the leaves onto the grass where one sits. In that particular moment, the shadow is most desirable, given that it is a warm day, making 
the space comfortable, but the light that made its way past the leaves was what truly beautified the space underneath the leaves. In this scenario, both light and shadow worked together, revealing each other's beauty.

There are numerous aspects of a building that are relational, meaning, their significance is emphasizes when paired up with their opposite, similar to the sunlight filtering through the leaves of a tree. The brightness of a white object was never fully acknowledged until it was placed side-by-side with the darkness of a black object. Both objects seem to reveal the identity of the other, allowing the perceiver to understand, visually, how bright the white object is and how dark the black object is. Their relationship, however, appears to be complementary rather than competitive. The white object desires for the perceiver to fully see the black object while the black object has the same wish for the white object. It becomes a completely selfless relationship between the two. Understanding this, the architect ought to emphasize key aspects of the building by also offering its opposite to reveal its significance. For instance, to emphasize the grandeur of the living room, the ceiling of the corridor or space leading up to the living room should be lower than the ceiling of the living room as a way to reveal the significance of the living room. The occupant may not find anything interesting about the ceiling heights until being suddenly surprised when it becomes 
raised. A space that receives plenty of sunlight may be desirable, not to mention beautiful, but would certainly not be as appreciated if the entire building received an equal amount of sunlight. In the same way, a building should consist of spaces that are deliberately left plain to elevate the beauty of another space.

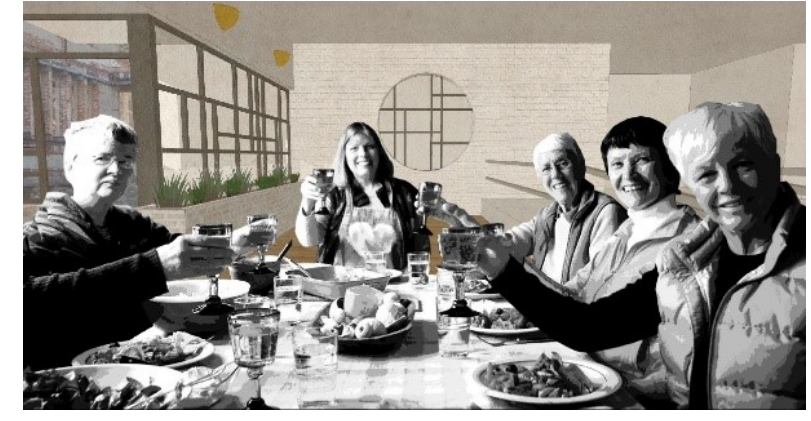

Figure 33 - Dining Room
Although a grand, well-lit, central space would make for a great public gathering space, for it to become well appreciated by the occupant let us also consider the alternative. Even someone who finds complete joy being in the company of others would enjoy the option of being able to escape to a denser and more private space to be alone with his/her own thoughts. Being around the company of others is often quite enjoyable but it also allows people to appreciate time alone. For this reason, it would be quite delightful for private spaces to be designed in a way that would well differentiate them from a public space; perhaps a room with windows that are placed strategically for minimal visual access from the outside. If this private space is a space in which one would not always be fully dressed, it would function best if to gain privacy the occupant didn't always need to shut the curtains. If the windows are placed away from the changing area, curtains may not even be necessary which would be beautiful simply in the way the space focuses on the human experience. If the space is meant to remain rather dark, allowing a small crack of light to enter, regardless 


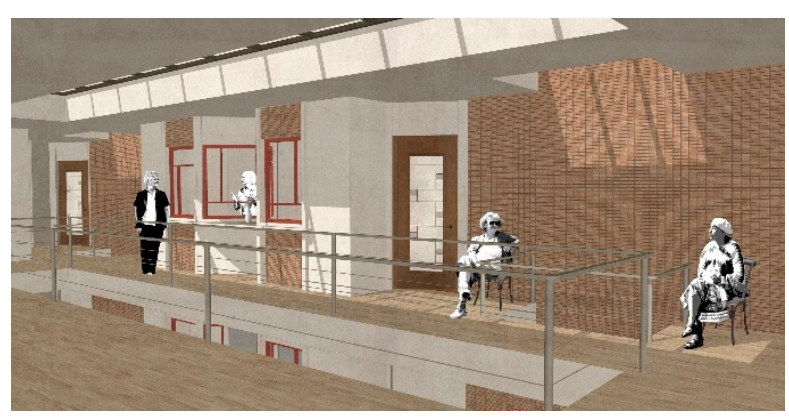

Figure 34 - Common Space if it is natural or artificial, would further emphasize how dark the space really is. What a delightful place to study that would be. A private space should have a low ceiling to emphasize that the space is meant for sitting, thinking, and productivity. Walls should not consist of too much detail since the occupant should be given the freedom of personalizing them as they please with book shelves, plants, paintings, etc. Floors should be made with hard material allowing for the addition of carpets and rugs according to the user's wishes. A public space in a residential building such as the kitchen, living room, and dining room should encourage interaction between people by creating key spaces that make conversations likely. A private space such as a bedroom, a study, or certain areas of a library, should enhance the ability to perform tasks and should be free from distractions. Having both private and public spaces in a building work in a complementary way to give unique significance to the other. Beauty occurs when the identity of a space is exalted by revealing how it, although different from all other spaces, plays a vital role in the function of the building. Beauty is also when the building offers all the tools and spaces that are desirable given different tasks and gives the opportunity for the occupant to choose which beautiful space is most suitable for them at different times. 
Every material carries unique ways of application. Bricks come in a variety of shapes and colors and can be stacked in countless different ways. Wood comes in different textures, can be hand crafted to reach miniature levels of detail, and can easily be used for furniture, flooring, window frames, etc. Concrete carries a heavy and dominating character and requires little help to bring attention to it. When combining any set of materials and seeking a way to do so appropriately, the key objective in this case is harmony. A painting could very well be considered beautiful but it is because each individual detail that was carefully placed made it such. Each color used may hold some beauty on its own, but it is only when all of them come together that we understand how they are, individually, complementary to one another. When things are firmly placed in their rightful places and come together to capture one mood or one function, they come together to create one beautiful thing which may also branch out into smaller individual beautiful things.

All materials that come together in one space should complement one another. The goal is not to bring attention to the fine detail of the individual materials but to create the desirable mood for the function of that space. Like musical notes being played at the wrong time, when harmony in a space is not achieved it will stand out quite obviously. If it becomes obvious what the architect was 'attempting' to achieve, it becomes clear that the architect has failed 
in designing that space since a successful space would capture the mood so well that it would give the occupant no chance to even notice it. A beautiful space functions harmoniously — making no room for distractions to be able to interfere. On a larger scale, the way spaces interact with one another should also be complementary. We learned earlier that this does not necessarily mean all spaces must work together for all of them to become beautiful, as a down-played space may bring out the beauty in the space adjacent to it. By complementary I simply mean that all spaces should be contributing to the overall goal of the building, whatever that may be. Beauty in the relationship of spaces is knowing that what one space lacks, another space gives. Together, all spaces ought to complete the overall function of the building as all the body parts complete the function of the body.

All spaces and details should be given careful attention by the architect and should be made unique and appropriate to its specific function but in order to produce a harmonious whole, they need to be guided by a similar language or strategy. If you pay close attention to a tree you will find that every single branch is quite different in the direction it points, its thickness, the number of leaves it holds, and possibly the quality of fruit it bears. Despite their differences, they still share, and are nourished by, the same roots. Every tree branch, although unique, can directly relate to all other branches. Regardless if one specific branch 
may be more desirable to hang a swing off of for children, all branches are one family with one source. It becomes quite beautiful when it is recognized that the relationship between two spaces on complete opposite ends of a building that serve two different purposes are cousins. To capture this language in a building there needs to be a source, a strategy, that all architectural decisions branch from. By this I do not only mean a materialistic language such as masonry, although, that may be an acceptable strategy, but it could be narrowed down to a single word that captures the objective of the building such as innovative, ecological, or influential. Unity could be found in a color scheme that is subtle and undisruptive or it could be the complete opposite. It could be the strict following of a set of rules or a commitment to not follow a single rule, which would, in itself, be the rule. Regardless, the architect should be guided by a language that is carried throughout the entirety of the building design allowing the individual spaces and details to act as a family sharing a common ancestor.

We mentioned earlier how harmony must be apparent in the design of a building. If this will truly be one of our objectives we must also consider the way we integrate structure, services, and accessibility into a design. The aspects of architecture that allow it to function as a machine for living provides a beauty of its own, as they allow us to understand how a building 
provides services for us. Often, we are quick to hide the joists, I-beams, pipes and vents behind a drywall or above a drop ceiling. Keeping these building necessities away from our field of vision is one strategy to achieve beauty. It is a beauty that focuses on the ability of surfaces to fashion an atmosphere. In this case, mystery is seen as an asset.

An alternative strategy is to think of beauty being revealed when we are allowed to understand how things work. A space in which the 'bones' and 'guts' are intertwined into the design visually encourages a deeper relationship between humans and the structures in which they dwell. To help understand this point, consider how the friendship between two people grows over time. It begins when the two realize they share a common similarity or interest. Over time, person 'A' begins to open up to person 'B' so person 'B' learns personal things about person ' $A$ ' which forces person ' $B$ ' to see person ' $A$ ' in new waysstrengthening their relationship. As they learn about each other, the value of their relationship grows continuously. Similarly, a very subtle beauty could grow throughout the time a person dwells in a building that reveals, in a pleasing way, what most buildings tend to hide. The perceiver would recognize, almost instantly, that a building revealing its greater identity is also giving an invitation for the occupant to linger in its complexity. It becomes a 
give-and-take relationship where the building gives the occupant comfort, security and a place to dwell while the occupant offers the beauty of the building a place to land.

Anyone who has walked through an art museum will agree that most paintings or photographs require a specific frame that displays the art work most appropriately. How one perceives the artwork is directly affected by the frame it rests in. Some frames are large some are small, some are thick some are thin, some are simple and others are quite ornate. Although our eyes may not notice, there is a direct connection between our experience of the artwork and the frame through which we are looking. As we walk through a museum, from a distance we see an art piece hanging on a white wall, pulling us closer to it, telling us there is something there worth our attention. We sense that the piece has been placed there carefully. If it were anywhere else our experience of that piece would not be the same. We walk closer and closer and then enter the experience the creator so desperately desired for us. As architects, we ought to determine where a window is placed based on the experience we want to bring from the outside into the field of vision of the occupant. This opening that allows us to see out and for sunlight to enter is quite an important asset to the experience of a space, and similar to paintings and photographs, the window itself, which behaves as the 'frame', directly affects that experience. All the details surrounding the window (i.e. mullions, 


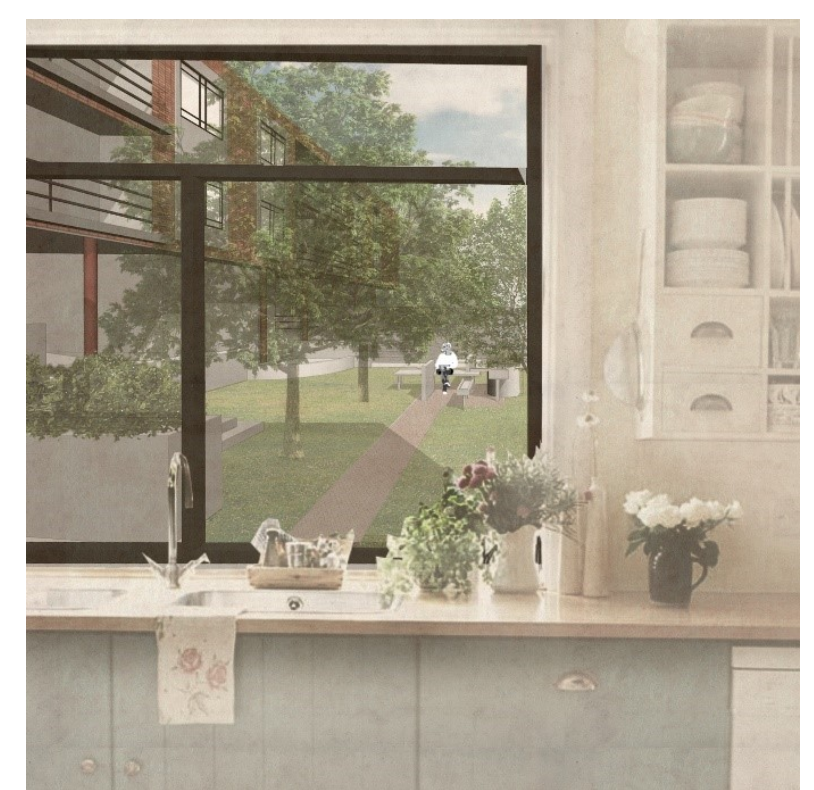

Figure 35 - Window Framing a Scene curtains, wall finishes, etc.) act as the 'frame' that enhances the experience of the scenery outside. The careful placement of windows is one way the architect is able to express the relationship he/she wishes for the building to have with the site. In spaces that we commonly sit in such as a bedroom, bathroom, or the dining room, windows should be low enough for the experience of sitting to not take away from what could be seen through a window. For a beautiful moment to occur the design of a space should focus primarily on the experience of the human body. Architecture should be generous and should make what is desirable accessible. Windows should allow one to see the garden, the sky, the trees, people walking, the pond, and birds. Secondly, not all windows serve the purpose of revealing beauty outside, some should also help inform where people are such as allowing one to see the mailman arriving with a package, a sibling sitting out on the porch, and the children playing in the yard. 


\section{Chapter 6: Concluding Remarks}

\subsection{Response to Thesis Question}

There is no single strategy for achieving beauty in architecture. Designing a beautiful moment is a complicated endeavor. My decisions were guided primarily by the attempt to achieve the needs and desires of an elderly woman seeking joy. Although creating an appealing space is an undoubtable aim, it seems the truer beauty that needed to be discovered were moments that allowed relationships to grow-not solely between women but also between the community and the neglected site. Achieving these moments is complicated as it is easier to know when you have got it wrong than when you have got it right.

That being said, the thesis has allowed me to explore a number of design strategies that I should be cognizant of and keep in mind as I move forward in practice. Graphical representation of a space may be more productive if it isn't literal.

With respect to the project itself, the process of design has allowed me to appreciate the practical design preconceptions that I have developed over the years that have a tendency 
to dominate at the expense of design strategies that are more focused on creating beauty. Since beauty leads us to truth, I learned to accept the design of a space when I came into agreement with how details were firmly placed and in good standing with its environment. Over the development of the design, I found myself constantly asking questions like, "what would one wish to see coming down the stairs" or "what would make for a delightful reading space in a library?" Offering each space and detail, large or small, thoughtful attention, seems to be an ethical obligation.

In addition, along the way, a few discoveries have been made; unintentional connections that seem relevant. There lies a direct correlation occurring between the program and the ruins of the Our Lady School building creating a beautiful relationship between the two. First both the site and the senior woman have been struggling to discover their purpose and how they contribute to our society. They have suffered a level of neglect as society has struggled to see the potential that remains in them. Over the years, they have aged and their beauty has changed but it is alive and well if they are given the right platform to reveal it. Much of their physical strength has been lost and they are in need of a proper support system that would allow them to thrive. 


\section{List of Illustrations}

Figure 1 - On Beauty and Being Just

Figure 2 - Lowertown West Aerial view

Figure 3 - St. Patrick Street, 1968

Figure 4 - 287 Cumberland Street

Figure 5 - Our Lady School, 2005

Figure 6 - Murray / Cumberland Intersection

Figure 7 - Our Lady School Interior, 2013

Figure 8 - Our Lady School Interior, 2013

Figure 9 - Our Lady School Exterior, 2017

Figure 10 - Our Lady School Interior, 2017

Figure 11 - Our Lady School - Material

Figure 12 - Our Lady School - Material

Figure 13 - Our Lady School - Development Proposal

Figure 14 - Our Lady School - Development Proposal

Figure 15 - Our Lady School Interior, 2017

Figure 16 - Our Lady School Interior Detail, 2017

Figure 17 - Being Mortal: Medicine and What Happens in the End

Figure 18 - Babayagas' House Founders

Figure 19 - Senior Women Together 
Figure 20 - Form + Space Diagram

Figure 21 - Site Analysis

Figure 22 - South Elevation

Figure 23 - West Elevation

Figure 24 - First Floor Plan

Figure 25 - South - North Section

Figure 26 - Second Floor Plan

Figure 27 - North - South Section

Figure 28 - Third Floor Plan

Figure 29 - Basement Floor Plan

Figure 30 - Garden

Figure 31 - Bedroom

Figure 32 - Transition Space

Figure 33 - Dining Room

Figure 34 - Common Space

Figure 35 - Window Framing a Scene 


\section{Bibliography}

\section{Lowertown West Heritage Conservation District}

Lowertown West Heritage Conservation District. (2011, September 28). Retrieved October 17, 2016, from http://www.historicplaces.ca/en/rep-reg/place-lieu.aspx?id=8446

\section{Lowertown Basseville Community Association}

Bernstein, L. (2015, December 15). Re: Demolition of 281-283 Cumberland, 287 Cumberland site development, using the retained walls of the former school on this site. Infill at vacant property 207-209 Murray (Rep. No. 36575403182017050433950). Retrieved September 23, 2016, from Lowertown Basseville Community Association website: http://app05.ottawa.ca/sirepub_fr/cache/2/c0zf3hddltw4t11oopejsios/36575403182017050 433950.PDF

\section{Cultural Heritage Impact Statement}

Stewart, J. J. (2015, November 25). A Cultural Heritage Impact Statement: 287, 281-283 Cumberland Street \& 207 - 20 Murray Street Ottawa, Ontario [PDF]. Ottawa:

Commonwealth Resource Management, $p$.

\section{On Beauty and Being Just}

Scarry, Elaine. On Beauty and Being Just. Princeton, NJ: Princeton University Press, 1999. 


\section{On Beauty and Being Just: Book Review}

Nehamas, A. (2000, June 21). Not Rocket Science. Retrieved January 20, 2017, from

https://www.lrb.co.uk/v22/n12/alexander-nehamas/not-rocket-science

\section{Being Mortal: Medicine and What Matters in the End}

Gawande, Atul, author. (2014). Being Mortal: Medicine and What Matters in the End. New York: Metropolitan Books, Henry Holt and Company.

\section{Everyman}

Roth, P. (2008). Everyman. Rearsby: Clipper Large Print.

\section{Application to Demolish (John L. Moser)}

Moser, J. L. (2015, December 10). Application to demolish 281-283 Cumberland Street and Application for new construction at 281-283 Cumberland, 297 Cumberland Street and 207-209 Murray Street, properties located in the Lowertown West Heritage Conservation District (Rep. No. ACS2015-PAI-PGM-0182). Retrieved September 27, 2016, from City of Ottawa Department of Planning and Infrastructure website: http://app05.ottawa.ca/sirepub/cache/2/0ei04iu4bnnpaqjxex3yeogh/325725031720170442 48817.PDF.

\section{Observations on the Feeling of the Beautiful and Sublime}

Kant, I., \& Goldthwait, J. T. (1981). Observations on the Feeling of the Beautiful and Sublime. Berkeley: University of California Press. 


\section{Women in Canada Statistics: 2010}

Milan, A., \& Vézina, M. (2010). Women in Canada, 2010: a gender-based statistical report (503rd ed., Vol. 89, X) (Canada, Government of Canada, Statistics Canada). Ottawa, ON: Statistics Canada. Retrieved October 10, 2016, from

http://www.statcan.gc.ca/pub/89-503-x/2010001/article/11441-eng.htm\#a21

\section{Observations on the Feeling of the Beautiful and Sublime}

Kant, I., \& Goldthwait, J. T. (1981). Observations on the Feeling of the Beautiful and Sublime. Berkeley: University of California Press.

\section{Babayaga's House}

Hird, A. (2013, March 05). The Babayagas' House, a Feminist Alternative to Old People's Homes, Opens in Paris. Retrieved January 10, 2017, from hitp://en.rfi.fr/france/20130305-

babayagas-house.

\section{The Hand and the Soul: Aesthetics and Ethics in Architecture and Art}

Iliescu, S. (2009). The Hand and the Soul: Aesthetics and Ethics in Architecture and Art. Charlottesville: University of Virginia Press.

\section{On Architecture}

Pollio, M. V. (2009). On Architecture (R. Schofield, Trans.). New York, NY: Penguin Group 


\section{Carlo Scarpa: The Complete Works}

CoFrancesco, D., \& M. (1984). Carlo Scarpa: The Complete Works. Milano, NY: Electa EditriceRizzoli.

\section{Recovering Landscape}

Corner, J. (1999). Recovering Landscape. New York, NY: Princeton Architectural Press.

\section{The Discipline of Architecture}

Piotrowski, Andrzej, Julia W. Robinson, and David Leatherbarrow. (2001) The Discipline of Architecture. Minneapolis, MN: University of Minnesota Press.

\section{On the Art of Building: In Ten Books}

Alberti, Leon Battista. On the Art of Building: In Ten Books (1992). Cambridge, MA: MIT Press.

\section{On Ugliness}

Eco, U. (2011). On Ugliness. New York, NY: Rizzoli.

\section{The Beauty of Justice}

Perez-Gomez, Alberto. (2012) "The Beauty of Justice," in Where are the Utopian Visionaries? Architecture of Social Exchange, New York, NY: Periscope/Prestel Publishing 


\section{Architect's Act Ontario}

Architects Act, R.S.O. 1992, C. A.26. "Ontario.ca. 1 June 2011. Web. 13 Apr. 2016

\section{Elements of Architecture: From Form to Place}

Von Meiss, Pierre. (1992). Elements of Architecture: From Form to Place. London: E \& FN Spon., p. 121 